HNF-5639

Revision 0

\title{
Summary of Model Toxics Control Act (MTCA) \\ Potential Impacts Related to Hanford Cleanup and the Tri-Party Agreement (ATP)
}

Prepared for the U.S. Department of Energy

Assistant Secretary for Environmental Management

Project Hanford Management Contractor for the

U.S. Department of Energy under Contract DE-AC00-9oRL13200

Fluor Hanford

P.O. Box 1000

Richland, Washington 


\section{INFORMATION CLEARANCE FORM}

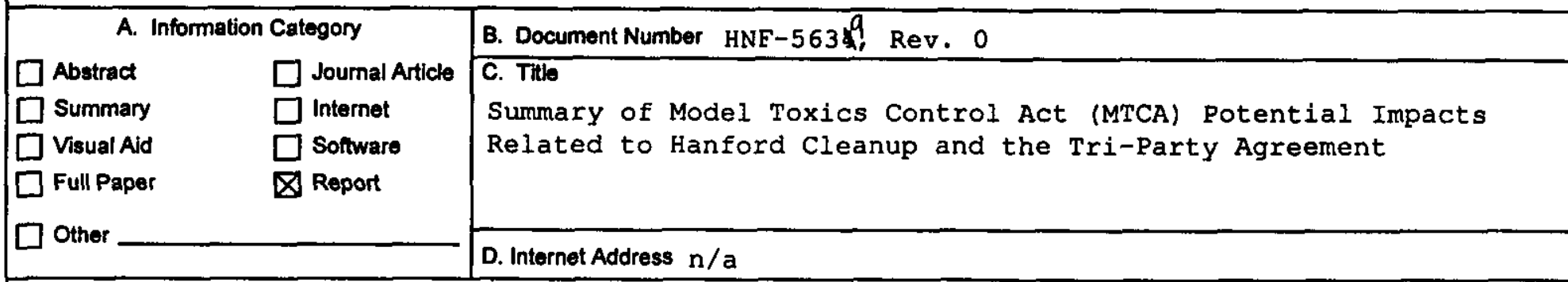

E. Required Information

1. Is document potentially Classified? $\square$ No $\square$ Yes (MANDATORY)

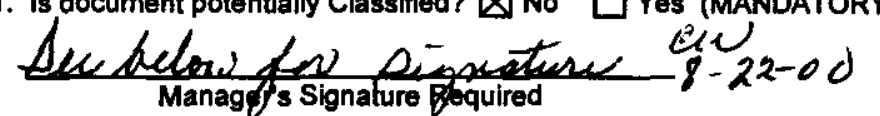

If Yes

4. Does Information Contain the Following: (MANDATORY)

a. New or Novel (Patentable) Subject Matter? $\triangle$ No $\square$ Yes

If "Yes", Disclosure No.:

b. Information Received In Confidence, Such as Proprietary and/or Inventions? $\triangle$ No $\square$ Yes if "Yes", Affix Approprlate Legends/Notices.

c. Copyrights? $\bigotimes$ No $\square$ Yes If "Yes", Attach Permission.

d. Trademarks? $\bigotimes$ No $\square$ Yes if "Yes", Identify in Document.

2. Internal Review Required?

If Yes, Document Signatures Below

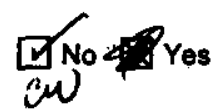

Counsel

Program

3. References in the Information are Applied Technology $\bigotimes_{\text {No }} \square$ Yes Export Controlled Information $\triangle N_{0} \square$ Yes
-

5. Is Information requiring submission to OSTI? $\bigotimes$ No $\square$ Yes If Yes UC-_ and $B \& R$ -

6. Release Level? \ Public $\square$ Limited

7. Charge Code 100017

\section{HMFDOY/1}

F. Complete for a Journal Article

1. Title of Journal $\mathrm{n} / \mathrm{a}$

G. Complete for a Presentation

1. Title for Conference or Meeting $\mathrm{n} / \mathrm{a}$

2. Group Sponsoring $\underline{n / a}$

3. Date of Conference $n / a$

5. Will Information be Published in Prodeedings? $\square$ No $\square$ Yes

D. Author/Requestor (Print and Sign)
I. Roviewers
Yes Print
General Counsel
区
Office of External Affairs
DOE-RL
区 $\square$ Hector M. Rodriquez
Other
$\square$
Stephen B. Cherry
Other Signature
J. If Information Includes Sensitive Information and is not to be released to the Public indicate category below.
$\square$ Applied Technology
$\square$ Protected CRADA
$\square$ Personal/Private
$\square$ Export Controlled
$\square$ Proprietary
$\square$ Procurement-Sensitive
X Business-Sensitive
$\square$ Patentable
$\square$ Predecisional
$\square$ Other (Specify)
TUCNI

4. City/State $\mathrm{n} / \mathrm{a}$

6. Will Material be Handed Out? $\square$ No $\square$ Yes Responsible Manager

K. If Addjtional Comments, Please Attach Separate Șheet

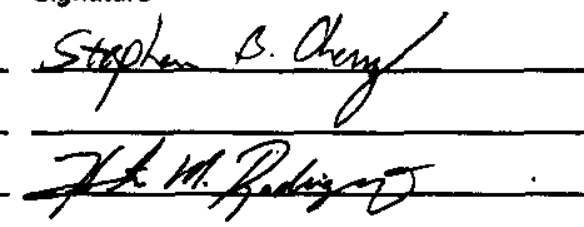

Public $\mathrm{Y} / \mathrm{N}$ (If $\mathrm{N}$, complete J)

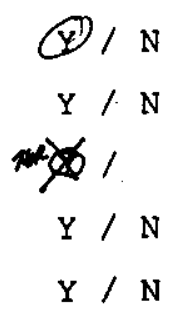

Information Clearance Approval

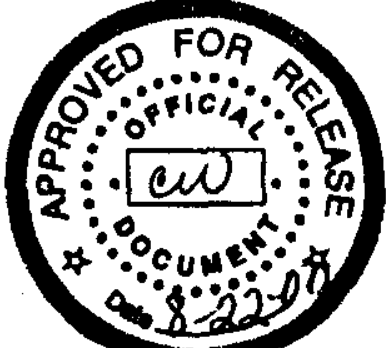




\section{Summary of Model Toxics Control Act (MTCA) Potential Impacts Related to Hanford Cleanup and the Tri-Party Agreement (ATP)}

Fluor Hanford Subcontract 6209, Vista Engineering Technologies, LLC Project VET-1005

J. Morse

Vista Engineering Technologies

D.F. Iwatate

Fluor Hanford, Inc.

Date Published

August 2000

Prepared for the U.S. Department of Energy

Assistant Secretary for Environmental Management

Project Hanford Manegement Contractor for the

U.S. Department of Energy under Contract DE-ACOE-SeRL13200

Fluor Hantord

P.O. Box 1000

Richlend, Woshington

$\frac{\text { Chies Srillenghemd }}{\text { Release Approval }} \frac{8 / 22 / 00}{\text { Date }}$ 


\section{LEOAL DISCLAIMER}

This report wes prepared as an account of work sponsored by an soency of the Unked States Government. Nelkher the Unitod States Government nor any agency thereof, nor any of their employew, nor any of their contractors, subcontractore or their employees, makes any warranty, expreas or Implled, or secumes any legal thability or responsibility for the sceuracy. complatenese, or any third party's use or the results of such uee of any information, apparatus, product, or proceses diecloesed, or reprecents that lits use would not infringe prlvately owned rights. Reference herein to any specific commercial product, proceses, or service by trade name, trademark, manuflacturer, or otherwise, does not necesaarly conattute or Imply tis endoreement, recommendation, or favoring by the Uniked States Government or any agency thereof or he contrectore or subcontractors. The viewe and opinions of authore expreased herein do not necesearlly etate or reflect those of the United Stetes Government or any agency thereof.

This report hes been reproduced from the beet available copy. 
July 17,2000

Fluor Hanford, Inc.

P.O. Box 1000

Richland, WA 99352

Attention: Jeff Hetzel

Subject: Vista Engineering Technologies, LLC Contract Deliverable, "Summary of Model Toxics Control Act (MTCA) Potential Impacts Related to Hanford Cleanup and the Tri-Party Agreement"

Dear Jeff:

Vista Engineering Technologies, LLC is pleased to submit five copies of the subject white paper. PHMC document number HNF-5634, Rev. 0 has been reserved for formal release of this report.

If you have questions please contact me directly at (509) 375-3374.

Sincerely,

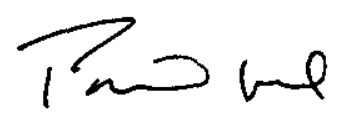

Phillip C. Ohl, P. E.

General Manager

Enclosures

cc: Peter Braun 
SUMMARY OF MODEL TOXICS CONTROL ACT (MTCA)

POTENTIAL IMPACTS RELATED TO HANFORD CLEANUP AND THE TRI-PARTY AGREEMENT (TPA)

Fluor Hanford Subcontract 6209

Vista Engineering Technologies, LLC Project VET-1005

Prepared by:

John Morse

Prepared for:

U.S. Department of Energy - Office of Regulatory Liaison c/o Fluor Hanford Corporation

P.O. Box 1000

Richland, WA 99352

Under Contract DE-AC06-96RL13200

July 14,2000 
HNF-5639, Rev. 0

\section{This page intentionally blank}




\section{Table of Contents}

Acknowledgements

Executive Summary iv

1. Introduction 1

2. Background 2

3. Analysis of Issues $\quad 2$

4. Conclusions $\quad 4$

Appendix A Model Toxics Control Act Detailed Analyses of Potential Issues for Hanford Cleanup A-1

Appendix A.1 Non-Radiological Soil Cleanup Standards $\quad$ A-2

Appendix A.2 Non-Radiological Groundwater Cleanup Standards $\quad$ A-5

Appendix A.3 Radiological Cleanup Standards $\quad$ A-8

Appendix A.4 Risk Assessment

Appendix A.5 Terrestrial Ecological Evaluation Procedures $\quad$ A-14

Appendix A.6 Remedy Selection $\quad$ A-18

Appendix A.7 Land Use Assumptions

Appendix A.8 MTCA Practice Around The State A-25

Appendix A.9 Association of Washington Business Position on MTCA A-28

References: $\quad$ A-30

Appendix B Hanford Site Comments on Proposed Changes To Model Toxics Control Act

Cleanup Regulations

B-1 


\section{Acknowledgements}

This report was compiled with contributions and reviews provided by: Mr. Barry Vedder, Ms. Linda Johnson, Mr. Jack Donnelly, Ms. Pam Doctor, and Ms. Janet Badden of Bechtel Hanford Incorporated, Mr. H. T. Tilden and Mr. D. K. Lutter of the Pacific Northwest National Laboratory, Mr. Fred Ruck, Ms. Deborah Iwatate, Mr. Jeff Hertzel, Mr. Wayne Toebe, and Ms. Marcia Berry of the Flour Hanford Corporation, Ms. Barbara Williamson of the Department of Energy and Mr. Phil Ohl and Mr. John Morse of Vista Engineering Technologies, LLC. 
This white paper provides an initial assessment of potential impacts of the Model Toxics Control Act (MTCA) regulations (and proposed revisions) on the Hanford site cleanup and addresses concerns that MTCA might impose inappropriate or unachievable clean-up levels and drive clean-up costs higher. The white paper and supporting documentation (Appendices A and B) provide DOE with a concise and up-todate review of potential MTCA impacts to cost and schedule for the Hanford site activities.

MTCA, Chapter 70.105D RCW, is the State of Washington's risk based law governing clean-up of contaminated sites and is implemented by Ecology under the MTCA Clean-up Regulations, Chapter 173340 WAC. Hanford cleanup is subject to the MTCA requirements as Applicable, Relevant and Appropriate Requirements (ARARs) for those areas of Hanford being managed under the authority of the Federal Resource Conservation and Recovery Act (RCRA), Comprehensive Environmental Response, Compensation and Liability Act (CERCLA), and the state Dangerous Waste Regulations.

MTCA provides Ecology with authority to implement site clean-up actions under both the federal RCRA and CERCLA regulations as well as under MTCA cleanup regulations. Most of the Hanford clean-up actions are being implemented under the CERCLA program, however, there is a trend is toward increased use of MTCA procedures and standards. The application of MTCA to the Hanford clean-up has been an evolving process with some of the Hanford clean-up actions considering MTCA standards as an ARAR and using MTCA procedures for remedy selection. The increased use and application of MTCA standards and procedures could potentially impact both cost and schedule for the Hanford cleanup.

To evaluate potential impacts, seven different issue areas on MTCA standards and procedures were identified and reviewed. A summary of this review is provided in the white paper and detailed analyses of the issues are presented in Appendix A. Supporting the analyses are the January, 2000 detailed DOE comments to Ecology on the proposed MTCA rule revisions (Appendix B). Based on the review, the issues fall into three categories: 1) little or no impact on cost and schedule; 2) potentially moderate negative impact on cost and schedule; and 3) potentially significant negative impact on cost and schedule.

The issue with little or no impact is remedy selection. The procedures differ somewhat between MTCA and CERCLA (which is currently being used at Hanford) but no significant impacts are anticipated. In some cases the MTCA process may be more straightforward and have a net positive impact. However, there are some ambiguities in the current and proposed MTCA regulations that will require clarification and negotiation with Ecology.

The issues with potentially moderate negative impacts on the Hanford clean-up cost and schedule include non-radiological soil and groundwater clean-up standards and risk assessment. Currently, the nonradiological standards and risk assessments at the site are based on the EPA RCRA and CERCLA guidelines. In general the MTCA clean-up levels imposed by these requirements are similar to the EPA requirements. However, some of the MTCA standards and risk assessment assumptions are more stringent which could impact cost and schedule. Overall the MTCA requirements appear to be achievable. An important consideration is that the revised MTCA risk assessment requirements not be applied to past remedial/removal actions at Hanford. Other potential concerns are ambiguities in establishing alternative risk exposure scenarios and groundwater protection requirements.

The issues with potentially significant negative impacts on the Hanford clean-up cost and schedule are radiological clean-up standards, the new terrestrial ecological evaluation procedures, and land use classification/assumptions. Currently the site uses a $15 \mathrm{mrem} / \mathrm{y}$ guidance to establish the appropriate radiological cleanup levels. This is basically a consensus standard that is in concurrence with The State of Washington DOH, EPA, NRC and DOE guidelines. This is a dose-based standard that if converted to an equivalent cancer risk based number would be on the order of $10^{-4}$. MTCA on the other hand, uses $10^{\circ}$ 
${ }^{5}$ or $10^{-6}$ cancer risk based criteria to set cleanup limits. A strict application of MTCA risk based standards could, therefore, potentially result in 100-fold decrease (more stringent) in the clean-up criteria at Hanford. This would greatly impact cost and schedule and is also currently unachievable.

The new terrestrial ecological evaluation procedures in the proposed MTCA revision could also potentially result in a ten-fold decrease (more stringent) in soil clean-up standards that would significantly impact cost and schedule.

Currently, at the site, remedy selection and cleanup levels have and are based on an assumed future land use classification of "industrial". MTCA has provisions in the current version to allow classification of most Hanford sites as "industrial use." This allows less stringent cleanup levels and lower costs than a "residential use scenario." However, Ecology has indicated some resistance to the industrial classification at Hanford because it is not zoned under the Growth Management Act. This issue has not been resolved and the proposed revisions could make the issue harder to resolve. If the more stringent "residential use" scenarios in MTCA were to be imposed then there would be a significant impact on cost and schedule for Hanford cleanup.

The potential impacts of MTCA range from little or none to fairly significant impacts to cost and schedule for Hanford cleanup. Implementation of Ecology's proposed revisions to MTCA have been delayed due to procedural issues in the rule making process. In the interim, Ecology is continuing the review of comments from DOE, The Association of Washington Business and other interested parties with the intent of incorporating the comments into a new revised rule. During this process, many of the issues and potential impacts to the Hanford cleanup may be resolved or lessened.

The MTCA rule-making process is in flux and the potential impacts from the regulation are subject to change depending on the outcome of negotiations between stakeholders and Ecology and the resulting revised rule. In addition, groups such as the Regulatory Path Forward Working Group are working on the radiological cleanup standards issue and others, that relate to final disposition of the Hanford site aggregated areas. All of these factors could influence the potential impacts from MTCA on the Hanford cleanup and should continue to be monitored on a routine basis. 


\section{MODEL TOXICS CONTROL ACT \\ POTENTIAL ISSUES TO HANFORD CLEAN-UP \\ WHITE PAPER}

\section{INTRODUCTION}

This white paper provides an initial assessment of the potential impacts of the Model Toxics Control Act (MTCA) regulations (and proposed revisions) on the Hanford site cleanup and addresses concerns that MTCA might impose inappropriate or unachievable clean-up levels and drive clean-up costs higher. The white paper and supporting documentation (Appendices $\mathbf{A}$ and B) provide DOE with a concise and up-to-date review of potential MTCA impacts to cost and schedule for the Hanford site activities.

MTCA, Chapter 70.105D RCW, is the State of Washington's risk based law governing clean-up of contaminated sites and is implemented by The Washington Department of Ecology (Ecology) under the MTCA Clean-up Regulations, Chapter 173-340 WAC. Hanford cleanup is subject to the MTCA requirements as Applicable, Relevant and Appropriate Requirements (ARARs) for those areas of Hanford being managed under the authority of the Federal Resource Conservation and Recovery Act (RCRA), Comprehensive Environmental Response, Compensation and Liability Act (CERCLA), and the state Dangerous Waste Regulations.

MTCA provides Ecology with authority to implement site clean-up actions under both the federal RCRA and CERCLA regulations as well as the state regulations. Most of the Hanford clean-up actions are being implemented under the CERCLA program, however, there is a trend is toward increased use of MTCA procedures and standards. The application of MTCA to the Hanford clean-up has been an evolving process with some of the Hanford clean-up actions considering MTCA standards as an ARAR and using MTCA procedures for remedy selection. The increased use and application of MTCA standards and procedures could potentially impact both cost and schedule for the Hanford cleanup.

The Department of Ecology's powers and duties under MTCA include:

- Provide for identification, investigation and clean-up of facilities where hazardous substances have come to be located

- Establish clean-up standards and select clean-up actions

- Carry out all state programs authorized under CERCLA and RCRA

- Enforce institutional controls and deed restrictions

- Provide for public participation

- Provide for hazardous substance release reporting

- Apply industrial clean-up standards at industrial properties

- Establish a hazard ranking system for hazardous waste sites

MTCA is presently undergoing a revision that will modify the existing clean-up standards, risk assessment methods, remedy selection and add new terrestrial ecological standards. This white paper and supporting documentation (Appendices A and B) provide DOE with a concise and upto-date review of potential MTCA impacts to Hanford cleanup. 


\section{BACKGROUND}

MTCA was passed by the voters of the State of Washington in 1989. Ecology regulations were adopted in early 1990s. MTCA has had confusing and conflicting interpretations over the years, and has been amended several times by the legislature. MTCA was formally amended in 1996. A 22 member Policy Advisory Committee (PAC) was formed in 1995 to develop consensus recommendations to improve MTCA. In December 1998, The Draft Rule Revision was released by Ecology for comment and review by external advisory groups and other interested parties (including DOE). The Proposed Rule Revisions were subsequently released by Ecology in late November 1999 for final review and comment. DOE submitted comments to Ecology on the proposed MTCA rule revisions in January 2000. The draft and proposed MTCA rule revisions still have numerous unresolved issues between Ecology and interested groups that may impact the Hanford cleanup. These issues and other potential impacts are discussed in this white paper.

The implementation of the Proposed Rule Revisions was recently delayed due to procedural issues in the rule making process. As a result, Ecology is conducting an additional review of the comments provided by DOE, the Association of Washington Businesses and other interested parties. The current plan by Ecology is to incorporate the comments and suggested changes to a new rule revision that should be ready for final public comment in the Fall of 2000. The delay and modification of the proposed rule revisions will provide DOE and others with an opportunity to try and resolve procedural and technical issues and reduce potential impacts from the eventual revisions to MTCA.

\section{ANALYSIS OF ISSUES}

To analyze potential impacts of MTCA on Hanford cleanup and initial set of 14 issues were reviewed. These were subsequently combined into seven key issues and two topical issues. These are:

$1 \quad$ Non-Radiological Soil Cleanup Standards

2. Non-Radiological Groundwater Cleanup Standards

3. Radiological Cleanup Standards

4. Risk Assessment

5. Terrestrial Ecological Evaluation Procedures

6. Remedy Selection

7. Land Use Assumptions

8. MTCA Practices Around The State

9. Association of Washington Business Position on MTCA

The detailed analyses of these issues are provided in Appendices A.1 through A.9.

The DOE comments on the proposed changes to MTCA, which were submitted to Ecology in January, 2000, also address specific concerns related to the seven key issues listed above. As appropriate, concerns identified in the DOE comments have been incorporated into the detailed analyses provided in Appendix A. In addition, a copy of the DOE comments is provided in Appendix B.

A summary of the potential impacts to Hanford cleanup for the seven key issues is provided on Table 1. A potential impact rating from 1 to 3 is provided in column 3. A rating of 1 implies little of no potential impact to the cost and schedule for Hanford cleanup, a 2 implies potentially 
moderate impacts and a 3 indicates potentially significant impacts. Column 4 lists the appropriate section with Appendix A and the pages in Appendix B where relevant comments can be found.

Table 1. Summary of Potential Impacts to Hanford Cleanup for the Seven Key Issues

\begin{tabular}{|l|l|c|c|}
\hline \multicolumn{1}{|c|}{ Issue } & Potential Concerns/Requirements & $\begin{array}{c}\text { Potential } \\
\text { Impact* }\end{array}$ & $\begin{array}{c}\text { App. A Ref. \& } \\
\text { App. B pages }\end{array}$ \\
\hline $\begin{array}{l}\text { 1. Non-Radiological } \\
\text { Soil Cleanup Standards }\end{array}$ & $\begin{array}{l}\text { Soil removal, cleanup risk level and } \\
\text { protection of groundwater requirements }\end{array}$ & 2 & $\begin{array}{l}\text { A.1, and pages B-7, } \\
\text { B-8,B-9, \& B-12 }\end{array}$ \\
\hline $\begin{array}{l}\text { 2 Non-Radiological } \\
\text { Groundwater Cleanup } \\
\text { Standards }\end{array}$ & $\begin{array}{l}\text { Technical impracticability, MTCA may } \\
\text { be more rigorous than CERCLA, } \\
\text { Technical issues with MTCA standards }\end{array}$ & 2 & $\begin{array}{l}\text { A.2, and pages B- } \\
9, \text { B-12 }\end{array}$ \\
\hline $\begin{array}{l}\text { 3. Radiological Cleanup } \\
\text { Standards }\end{array}$ & $\begin{array}{l}\text { Issues regarding jurisdiction and } \\
\text { standards not resolved. DOH oversight } \\
\text { of radiological cleanup at Hanford }\end{array}$ & 3 & A.3 \\
\hline 4 Risk Assessment & $\begin{array}{l}\text { Justification for alternative exposure } \\
\text { scenarios, more stringent assumptions, } \\
\text { reevaluating past cleanup actions }\end{array}$ & 2 & $\begin{array}{l}\text { A.4, and pages B-7, } \\
\text { B-8 and B-9 }\end{array}$ \\
\hline $\begin{array}{l}\text { 5. Terrestrial Ecological } \\
\text { Evaluation Procedures }\end{array}$ & $\begin{array}{l}\text { Imposition of methods could potentially } \\
\text { reduce cleanup levels by factor of 10 }\end{array}$ & 3 & $\begin{array}{l}\text { A.5, and B-4,B-10, } \\
\text { B-11 and B-12 }\end{array}$ \\
\hline $\begin{array}{l}\text { 6. Reedy Selection } \\
\text { Similarity of RIFS methods, acceptance } \\
\text { of past and present CERCLA actions, } \\
\text { demonstrating "disproportionate costs" }\end{array}$ & 1 & $\begin{array}{l}\text { A.6, and pages B-3, } \\
\text { B-5, B-6 }\end{array}$ \\
\hline $\begin{array}{l}\text { 7. Land Use } \\
\text { assumptions }\end{array}$ & $\begin{array}{l}\text { Maintaining industrial land use } \\
\text { classification for Hanford cleanups }\end{array}$ & A.7, and pages B-3, \\
Potential cost and schedule impacts to Hanford cleanup: (1) little or none; (2) moderate; and (3) \\
significant.
\end{tabular}

The issue with little or no potential impact to Hanford cleanup is Remedy Selection (Issue 6), as shown on Table 1. The remedy selection process under MTCA is somewhat different than the Federal Cleanup Law (i.e. CERCLA/RCRA) that is currently used at Hanford, however, only small differences in cost and schedule for remedy selections are anticipated. Clarification is needed in the regulations to assure that past and current CERCLA actions also satisfy MTCA requirements and revisiting approved remedies will not occur. The demonstration of "substantial and disproportionate" costs in the alternate remedy selection process also needs clarification.

The issues with potentially moderate impacts to Hanford cleanup are Non-Radiological Soil and Groundwater Cleanup Standards (Issues $1 \& 2$ ) and Risk Assessment (Issue 4). The standards and methods for establishing soil and groundwater cleanup levels in MTCA are somewhat more stringent than under the CERCLA or RCRA EPA standards used at Hanford. MTCA, therefore, could potentially result in increased costs. The protection of groundwater from soil contamination and classification of groundwater as drinking water under MTCA is similar to current Hanford requirements. Overall, cleanup of non-radiological contaminants in soils and groundwater under MTCA is achievable but could potentially result in a moderate negative impact to the cost and schedule for Hanford cleanup. 
MTCA risk assessment assumptions are more stringent than current risk assessment methodologies at Hanford. This could result in increased costs for both conducting the risk assessment and implementing the resulting cleanup. Alternate risk methodologies are allowed which would lower costs but technical and procedural concerns with the current proposed revisions to MTCA need to be resolved first. The MTCA rules also need to be clarified to reflect that past risk assessments at Hanford would not have to be reevaluated. In light of uncertainty and unresolved issues, conducting risk assessments under MTCA could potentially have a moderate negative impact on cost and schedule for Hanford cleanup.

The three issues on Table 1 with potentially significant impacts on Hanford cleanup are Radiological Cleanup Standards (Issue 3), Terrestrial Ecological Evaluation Procedures (Issue 5), and Land Use Assumptions (Issue 7). Jurisdiction for regulation of radiological cleanup has not been fully resolved and final standards have not been promulgated. Through an MOU with Ecology, however, the Washington Department of Health (DOH) is the state agency that provides guidance and oversight of radiological cleanup actions at Hanford. The general consensus guidance between DOE, NRC, EPA and DOH for radiological cleanup is $15 \mathrm{mrem} / \mathrm{y}$. The concern is that increased use of MTCA methods could potentially result in a more stringent risk based standard that would be 10 to 100 times lower than the current guidance and would have a significant negative impact on the Hanford cleanup.

The draft Terrestrial Ecological Evaluation Procedures in the current proposed MTCA revisions have a number of technical and procedural problems which are discussed in Appendix A.5 and Appendix B. The main concern, however, is imposition of the measures in the current draft could potentially lower soil cleanup levels by a factor or 10 and significantly increase cleanup costs. These procedures should be significantly modified during the current ongoing review and revision process by Ecology for the MTCA rule revisions.

Hanford currently uses an "industrial" future land use classification as a basis for remedy selection and establishing cleanup levels. The MTCA nules and proposed revisions appear to allow an industrial classification for the 200 and 300 Areas at Hanford, however, some of the regulators at Ecology, (because Hanford is not zoned under the GMA process), claim the industrial classification should be not allowed. The lack of clarity in the current and proposed revisions to MTCA needs to be resolved in the ongoing MTCA revision process. Because of the current uncertainty, under MTCA, a residential scenario could potentially be imposed which would have a significant negative impact on Hanford cleanup.

\section{CONCLUSIONS}

The potential impacts of MTCA range from little or none to fairly significant impacts to cost and schedule for Hanford cleanup. Implementation of the proposed revisions to MTCA has been delayed due to procedural issues in the rule making process. In the interim, Ecology is continuing the review of comments from DOE, The Association of Washington Business and other interested parties with the intent of incorporating the comments into a new revised rule. During this process, many of the issues and potential impacts to the Hanford cleanup may be resolved or lessened.

The MTCA rule-making process is in flux and the potential impacts from the regulation is subject to change depending on the outcome of negotiations between stakeholders and Ecology and the resulting revised rule. In addition the Regulatory Path Forward Working Group is working on issues, such as the radiological cleanup standards, that related to final disposition of the Hanford site aggregated areas. All of these factors could influence the potential impacts to the Hanford cleanup and will continue to be monitored on a routine basis. 


\section{APPENDIX A \\ MODEL TOXICS CONTROL ACT}

DETAILED ANALYSES OF POTENTIAL ISSUES FOR HANFORD CLEANUP Appendix Page

A.1 NON-RADIOLOGICAL SOIL CLEANUP STANDARDS A-2

A.2 NON-RADIOLOGICAL GROUNDWATER CLEANUP STANDARDS A-5

A.3 RADIOLOGICAL CLEANUP STANDARDS A-8

$\begin{array}{ll}\text { A.4 RISK ASSESSMENT } & \text { A-11 }\end{array}$

A.5 TERRESTRIAL ECOLOGICAL EVALUATION PROCEDURES A-14

$\begin{array}{lll}\text { A.6 REMEDY SELECTION } & \text { A-18 }\end{array}$

A.7 LAND USE ASSUMPTIONS A-23

A.8 MTCA PRACTICE AROUND THE STATE A-25

A.9 ASSOCIATION OF WASHINGTON BUSINESS
POSITION ON MTCA

$\begin{array}{ll}\text { REFERENCES } & \mathbf{A - 3 0}\end{array}$ 


\section{APPENDIX A.1 \\ NON-RADIOLOGICAL SOIL CLEANUP STANDARDS}

Issue:

By applying existing provisions within MTCA, compliance with the $10^{-6}$ and $10^{-5}$ cleanup standards for lifetime cancer risk should generally be both achievable and measurable for nonradiological contaminants in soil. The Environmental Restoration (ER) program has completed a number of cleanup actions wherein MTCA standards representing the $10^{-6} / 10^{-5}$ cleanup levels were selected for nonradiological contaminants. Experience to date shows that these cleanup levels can be attained. In certain instances, analytical limitations did not accommodate measurement to the associated cleanup levels. In these instances, existing MTCA provisions in WAC 173-340-707 were used to allow the practical quantitation limit to suffice as demonstration that cleanup had been successfully completed. In certain other instances, the Hanford site background concentration exceeded the cleanup level. In these cases, the provisions of WAC 173-340-700(4)(d) were used to set the cleanup levels at the natural background concentration.

The current and proposed revisions to MTCA (in particular WAC 173-340 sections 700 through 747) have a number of unresolved technical and procedural issues regarding the use of the standards and risk based calculation for cleanup levels. A detailed set of comments on these sections are provided in Appendix B and are also discussed as appropriate below.

\section{Potential MTCA Impacts:}

There is concern that MTCA cleanup standards mandate removal of contaminants in all cases where the soil concentrations represent a risk in excess of the $10^{-6} / 10^{-5}$ cleanup levels and MTCA requires that soil cleanup be done to ensure that remaining concentrations are protective of groundwater. There is potentially a negative impact to cost and schedule for Hanford cleanup if these requirements were to be strictly interpreted.

\section{Current practice and implementation under MTCA:}

MTCA cleanup standards are flexible with regards to removal of contaminants where the soil concentrations represent a risk in excess of the $10^{-6} / 10^{-5}$ cleanup levels. MTCA does not require removal of waste in all cases where the risk in an unrestricted exposure scenario exceeds the risk levels. If this were the case, land filling of waste above the cleanup levels would arguably be prohibited under MTCA. Instead, MTCA recognizes that alternate points of compliance can be used in combination with containment technologies to reduce risk and leave waste above the $10^{-}$ $6 / 10^{-5}$ risk leveis in place. It is true that the default MTCA position requires removal of soil above cleanup levels to 15 feet below the ground surface. However, provisions at WAC 173-340740(6)(d) allow for alternate points of compliance. In practice, these provisions have been commonly used within the state to leave waste in place above the cleanup levels (in combination with containment technologies), even in current residential settings. In many instances, little or no removal of contaminants is required during MTCA cleanup actions, even though concentrations greatly exceeded the $10^{-6} / 10^{-5}$ risk levels under an unrestricted exposure scenario.

The MTCA requirement that soil cleanup be done to ensure that remaining concentrations are protective of groundwater may be problematic in certain situations. Meeting this requirement can be accomplished by excavating highly contaminated soils, by capping soils to prevent infiltration, 
or by using a combination of removal and capping technologies. The ER program efforts to date have successfully removed contaminated soil to levels that ensure groundwater protection. There has been speculation, however, that highly contaminated soils in the 200 Area Tank Farms may present challenges in terms of groundwater protection because the amount of soil excavation required would be extraordinary and capping alone would be insufficient to prevent movement of contaminants to groundwater. Further evaluation of the Tank Farms soil is required before the significance of this problem can be determined. In particular, the following questions need to be further considered from a technical standpoint before any conclusions can be reached regarding the ability to comply with MTCA soil cleanup requirements for groundwater protection:

- If relying solely on soil excavation to attain groundwater protection, how much removal would be required? At what cost?

- Can containment sufficiently prevent infiltration and mobilization of contaminants? If so, at what cost?

- Can a combination of excavation and containment be used to achieve groundwater protection? At what cost?

\section{Current and proposed revisions to MTCA soil cleanup standards:}

Ecology has revised MTCA to respond to concerns and comments with the intent of making the rules easier to understand, more flexible and less ambiguous and expensive to implement. Based on the comments provided in Appendix B, this objective has not been met in the current version of the proposed revisions to MTCA. In particular, the soil to groundwater protection provisions are so technically involved as to be unreadable. The proposed revisions appear to contain confusing or incorrect references to the $10^{-5}$ risk level and apparent flawed statistical methods. The specific technical and procedural issues, discussed in Appendix B, that are of concern for Hanford non-radiological soil cleanup, are:

- WAC 173-340-700(5)(b); WAC 173-340-700(5)(c); WAC 173-340-706(1)(b): Based on the language in Section 706(1)(b), it appears that Ecology has now restricted use of Method C for soils to industrial soils only and the reference to the $10^{-5}$ risk level should be clarified.

- WAC 173-340-706(1)(a)(i): Language retained in this section deals with instances where Method A or Method B cleanup levels are below area background concentrations and Method $\mathrm{C}$ cleanup levels may be established at concentrations that are equal to area background concentrations. There is concern that This requirement could require a cleanup standard that, in certain situations, is below background levels.

- WAC 173-340-720(8)(b): The proposed language in this section appears to require a downward adjustment of cleanup levels based on applicable state or federal laws where levels exceed a hazard index of one. Requirements of this section need to be clarified and revised.

- WAC 173-340-720 (10)(d)(iii). There is concern that the standards given in the revised MTCA tables are derived using a flawed statistical method. There is also concern about the presumption that groundwater levels exceed cleanup levels (definition of "null hypothesis" in 173-340-200). 
- WAC 173-340-745(5)(b)(ii): This section requires that contaminants left in industrial soil not cause groundwater to exceed cleanup levels established under WAC 173-340-720. Clarification is required as to which -720 groundwater cleanup levels are being referred to, Method $C$ levels (corresponding to use of Method $C$ for establishing industrial soil standards) or Method B levels (unless, under the $\mathbf{- 7 2 0}$ criteria, Method $\mathrm{C}$ levels can be justified).

- WAC 173-340-747: This section establishes a variety of methods for establishing soil cleanup concentrations for groundwater protection: two "standard Method B" methods and four "modified Method B" methods. Significant clarification is needed to interpret and use this section.

- WAC 173-340-990, Table 740-1, "Method A Soil Cleanup Levels for Unrestricted Land Uses," lead entry: The $250 \mathrm{mg} / \mathrm{kg}$ cleanup level for lead is purportedly based on "preventing unacceptable blood lead levels." This appears to be an outdated value.

\section{Conclusions:}

Experience to date shows that, in general, the MTCA soil cleanup levels for non-radiological contaminants can be attained. There are concerns regarding the requirements to remove all soils above the $10^{-6} / 10^{-5}$ cleanup levels and the requirement to achieve soil cleanup levels that are protective of groundwater. As currently practiced, these requirements are achievable and there is flexibility in MTCA to use alternate points of compliance and containment technologies to achieve required levels of protection. As listed above, there are also a number of unresolved issues and interpretations of MTCA. Although soil cleanup levels are achievable under MTCA, there could potentially be a moderate net negative impact on the overall cost and schedule for the Hanford cleanup. 


\section{APPENDIX A.2}

\section{NON-RADIOLOGICAL GROUNDWATER CLEANUP STANDARDS}

Issue:

Based on both the EPA's and the State of Washington's groundwater classification scheme, most of the Hanford groundwater is considered a potential future source of drinking water. The basis for this classification is that the physical characteristics of the groundwater prior to contamination would have allowed use as a drinking water source. (I.e., the classification scheme does not consider whether the groundwater is actually intended to be used for drinking water at some future date, only whether it would have been physically possible for the groundwater in a natural state to have been used for such purposes.)

The proposed Model Toxics Control Act (MTCA) regulatory amendments issued in November 1999 propose changes to the Method A, B, and C cleanup levels for soil and groundwater. Proposed changes to WAC 173-340-720 revise the cleanup levels applicable to groundwater. In many cases, the definitions of various groundwater sources have been revised, with the result that more stringent cleanup criteria apply to groundwater at the Hanford Site. The resulting changes have the potential to negatively impact the schedule and cost of remediation of known groundwater contamination at the site.

\section{Potential MTCA Impacts:}

Restoration of Hanford groundwater to allow for drinking water use may not be practicable. However, under either MTCA or CERCLA a technical evaluation will be necessary to support this position. The evaluation under MTCA may be more rigorous than that necessary under the CERCLA program, although this is somewhat uncertain. No added groundwater plumes would be created by the current proposed revisions to MTCA. However, new contaminants (MTBE, naphthalenes) would be added and may need to be analyzed for. Lower standards for total petroleum hydrocarbons (TPH) would result in possible additional analytical work, since TPHs are broken into subcategories in the proposed rule. For instance, the cleanup level for diesel range organics decreases from $1000 \mathrm{ppm}$ to $500 \mathrm{ppm}$. Additional cleanup may be necessitated in cases where operable units have been contaminated by hydrocarbon releases.

\section{Current Status:}

Remediation of groundwater contamination at the Hanford Site is currently managed through the Tri-Party Agreement (TPA). Where individual site operations have contaminated groundwater, the remediation is conducted as part of the unit's cleanup plan. Where contamination has resulted from multiple site operations or has traveled within the groundwater plume, groundwater "operable units" have been established to address these contaminated groundwater areas. Standards for cleanup are determined on a unit by unit basis, generally based on health-based limits similar to, but not equivalent to, MTCA cleanup levels.

It is widely believed that cleanup of many Hanford groundwater plumes to allow for drinking water use cannot be reasonably achieved. Examples of Hanford groundwater plumes where cleanup may not be achievable include plumes of tritium, carbon tetrachloride, and strontium-90. 
Both CERCLA and MTCA establish, as a default position, that groundwater classified as a potential future source of drinking water be remediated to attain standards for drinking water use within a reasonable time frame. However, both CERCLA and MTCA recognize that such remediation may not always be achievable, and thus provide for less rigorous cleanup actions. There is a strong correlation between CERCLA and MTCA allowances in this regard, and thus application of MTCA to Hanford should be relatively equivalent to that which would otherwise be required under CERCLA provided that the agenda of individual regulators can be removed from the process.

MTCA regulations recognize that cleanup of groundwater to allow for drinking water use within a reasonable time frame may not always be practicable. Like CERCLA requirements, the MTCA determination of practicability considers cost. The CERCLA standard for technical impracticability is based on costs being "inordinate"; the MTCA determination of impracticability is based on whether "the incremental cost of the cleanup action is substantial and disproportionate to the incremental degree of protection it would achieve."

Both CERCLA and MTCA assume a fairly rigorous evaluation of site-specific data (e.g., plume characterization, data from testing of potential remediation technologies) before concluding that groundwater remediation is impracticable. Thus, both programs mandate that groundwater not be "written off" without a significant evaluation as to the potential use of cleanup technologies. However, because of extensive experience gathered from actual cleanup efforts, the CERCLA program appears to be more mature than MTCA with regards to recognizing situations where restoration is impracticable. Thus, a determination of the impracticability of groundwater restoration may be somewhat easier to demonstrate under the CERCLA program.

\section{MTCA Flexibility:}

MTCA regulations require that, in situations where groundwater restoration is shown to be impracticable, containment technologies (e.g., barriers or hydraulic controls) shall be used to the extent practicable to avoid expansion of the contaminated plume. This principle is embodied in CERCLA as an expectation that measures will be taken to prevent further migration of the contaminated plume in situations where restoration is shown to be not practicable.

The proposed revision to MTCA appears to decrease the amount of flexibility on this issue, since more groundwater is made subject to the rule. In order to qualify for increased flexibility, the groundwater in question must either be "perched" (noncontiguous with surface water) or determined by Ecology to be unsuitable as a drinking water source for reasons given in WAC $173-340-720(2)(b)$. This determination is made on a case by case basis.

\section{Technical Concerns:}

There is concern within the groundwater monitoring program that the standards given in the revised MTCA tables are derived using a flawed method. Concerns were also raised concerning the presumption that groundwater levels exceed cleanup levels (definition of "null hypothesis" in 173-340-200). While this is appropriate when the cleanup levels are concentration-based, the MTCA amendments shift the cleanup levels to background levels in some cases. It is inappropriate to assume that the groundwater contains more than background levels as a starting hypothesis.

Cleanup levels are based on risks, ARARs, ecologically protective levels, etc. The statistical test is a one-sample test (i.e., evaluating the site data versus a constant or a fixed value). However 
when the cleanup levels are based on background, the statistical test is a two-sample case (i.e., evaluating the site data versus background data). Currently, the default method [as specified the in compliance monitoring (WAC-173-340-720 (10)] uses a single numerical value as the cleanup standard, to which site data is compared. To treat background-based cleanup levels as constants (known without error) will make it more difficult to simultaneously achieve a desirable (low) false positive error rate and a high statistical power to detect residual contamination if background data sets are highly variable (i.e., highly skewed distributions). Alternative distribution testing methods, such as the Wilcoxon Rank Sum test or the Quantile test (Gilbert, R.O. and J.C. Simpson, 1992), should be specified in WAC 173-340-720 (10)(d)(iii).

\section{Conclusions:}

Restoration of Hanford groundwater to allow for drinking water use may not be practicable. However, under either MTCA or CERCLA a technical evaluation will be necessary to support this position. The evaluation under MTCA may be more rigorous than that necessary under the CERCLA program, although this is somewhat uncertain. Both CERCLA and MTCA require plume containment, where practicable, in situations where restoration is shown to be impracticable. The mere changes to the groundwater requirements of WAC 173-340-720 do not appear to have a significant impact on the groundwater programs at the site. There are a number of technical and procedural issues regarding the use of MTCA based groundwater cleanup standards that have not been resolved. However, it appears, that the current and revised MTCA groundwater cleanup standards potentially will have only a moderate impact on the cost and schedule for Hanford cleanup. 


\section{APPENDIX A.3}

\section{RADIOLOGICAL CLEANUP STANDARDS}

Issue:

MTCA regulations and standards do not specifically address radiological cleanup standards. Currently there are no final applicable state or federal regulations for radiological cleanup. Draft proposed guidelines have been published by EPA (40 CFR Part 1960 and NRC (10 CFR Part 20) and the Washington Department of Health (DOH) has issued an interim Radiological Guidance (RG) (Washington Department of Health, 1997) for Hanford cleanup which is consistent with EPA and NRC guidance. In addition, there is no final resolution of jurisdiction and authority to regulate radiological cleanup standards at Hanford.

DOH is recognized as the primary state agency for protection of human health and the environment from ionizing radiation. This authority is designated in Chapter $70.98 \mathrm{RCW}$ and through the Memorandum of Understanding (MOU) (Washington Department of Health, 1994) between DOH and the Washington Department of Ecology (Ecology). DOH regulates the cleanup of radioactive wastes and facilities under Chapter $70.98 \mathrm{RCW}$ and under the Hanford Federal Facility Agreement and Consent Order (TPA) and Ecology is the state agency designated to oversee Hanford cleanup. The $\mathrm{DOH}$ role is to review and provide recommendations to Ecology on radiological aspects of the Hanford cleanup. Thus, through the MOU, DOH guidance and standards for radiological cleanup can be applied under MTCA setting a precedent for regulation of radiological cleanup under MTCA.

Impact:

If the MTCA approach for establishing non-radiological contaminant cleanup standards is also used in calculating permissible residual radionuclide concentrations, the potential impact would be to significantly reduce the clean-up levels in soil and groundwater by at least an order of magnitude. This could potentially have significant cost and schedule impacts on the Hanford cleanup.

\section{Current DOH Guidance:}

DOH has not issued an environmental radiation standard through the state rulemaking process. The interim RG (State of Washington Department of Health Interim Regulatory Guidance, Hanford Guidance for Radiological Cleamup), however, was issued in 1997 to meet the need for consistent radiological standards for environmental cleanup at the Hanford sties since there are no applicable state or federal regulations for radiological cleanup. The interim RG is expected to be evaluated as a "to be considered" requirement of the National Contingency Plan Subpart EHazardous Substance Response and CERCLA Section 121 - Cleanup Standards. The interim RG uses a dose-based guidance for remediation of radiologically contaminated soil, groundwater, materials, and structures at the Hanford Site that will allow sites and facilities to be released for public use. The dose limit for release of a site is $15 \mathrm{mrem} / \mathrm{y}$ Total Effective Dose Equivalent (TEDE). This limit is consistent with the $15 \mathrm{mrem} / \mathrm{y}$ guidance by EPA and NRC. This limit is also consistent with the Interim Remedial Action Objective in the 100 Area Recond of Decision, which is the guidance being used for current Hanford cleanup under the TPA. 


\section{Discussion:}

Hanford cleanup is subject to the MTCA requirements as Applicable and Relevant and Appropriate Requirements (ARARs) under CERCLA and for RCRA closure and corrective action. In general, RCRA prohibits the treatment, storage or disposal of hazardous waste at both private and governmental facilities without a permit issued by EPA or an authorized state. (See, 42 USC $\$ \S 6925$ (a) and 6961) Hazardous waste includes types of solid waste that for enumerated reasons create public health and environment dangers. Under RCRA, hazardous waste is a type of solid waste. The term "solid waste" does not include "source, special nuclear, or byproduct material as defined by the Atomic Energy Act (AEA) of 1954". (42 USC $\S 6903(27)$ ) The AEA governs these items and preempts RCRA (See, 42 USC $\$$ 6905(a)). 10 CFR Part 962 clarifies the meaning of the term "byproduct material" under section 1 le(1) of the AEA for use in determining DOE's obligations under RCRA with regard to radioactive waste substances owned or produced by the DOE pursuant to the exercise of its responsibilities under the AEA of 1954. To determine the applicability of RCRA to any radioactive waste substance owned or produced by the DOE the words "any radioactive material," as used in 962.3(a), refer only to radionuclides dispersed or suspended in the waste substance. The non-radioactive hazardous component of the waste substance will be subject to regulation under RCRA. Similar complicating jurisdictional issues also pertain to CERCLA actions at DOE facilities.

The issue of jurisdiction under AEA, RCRA and CERCLA and between DOE, NRC and EPA has not been formally resolved. However, EPA is authorized to protect human health and the environment from ionizing radiation and can set does limits for workers at radiological facilities and sites. The authorization to set dose limits can then flow down to the states (i.e. Washington DOH). While there has been no final agreement on jurisdiction and authority for setting radiological cleanup standards a general consensus has emerged which uses the dose based approach and with a current guidance of $15 \mathrm{mrem} / \mathrm{y}$.

\section{Application of $15 \mathrm{mrem} / \mathrm{y}$ Guidance vs. MTCA Requirements:}

A casual review of the public health standards that have been promulgated by both the State and Federal Agencies over the years reveals some significant differences in the level of protection for the general public from releases of radioactivity. This is exemplified in the potentially significant differences between the $15 \mathrm{mrem} / \mathrm{y}$ guidance and calculation of radiological standards using the MTCA risk methodology. Although all regulations adhere to the fact that standards should be risk-based, they differ on the level of protection and the degree of conservatism, or margin of safety, built into the standard. This degree of conservatism, usually expressed as a factor of risk, varies by several orders of magnitude. When this level of risk is converted to a level of contaminant concentration, the basis of this conservatism is lost and the impact on cost, schedule and effective occupational dose can be significant.

The current $15 \mathrm{mrem} / \mathrm{y}$ guidance is used to calculate the cleanup level required in soil, groundwater, material and structures at a given site. The limit is applied to the sum of radiation exposure from all pathways by which a person could reasonably be exposed to residual radioactivity. The EPA maximum exposure concept is the approach generally used for this analysis. This approach uses standardized exposure pathways and default exposure factor values to calculate maximum reasonable estimates of contaminant intake and risk for individuals in an exposed population. Institutional controls, alternate land uses, and engineered barriers may be utilized to limit exposure or control pathways. 
The dose-based limit for radionuclides is different than the conservative health risk based or statutory cleanup concentrations standards in MTCA for non-radioactive contaminants. Nonradioactive contaminants can generally be measured at much lower concentrations in a given media (soil or water) and the concern is with the chemical effects on living organisms of a given constituent. For radioactive constituents the concern is with the ionizing radiation effects and generally not the chemistry of the radionuclide. Thus dose-based limits are appropriate. For radioactive contaminants, the $15 \mathrm{mrem} / \mathrm{y}$ dose limit is generally achievable for site cleanup actions at Hanford, although for some radionuclides, the ability to monitor and detect at the required levels it is at the very edge of being technically feasible.

MTCA uses a conservative risk based approach to establishing clean up standards for nonradiological contaminants. In the November 1999 rule revisions proposed by Ecology, there are three options (A, B and C) for setting site-specific cleanup standards that involve various potential land use scenarios (residential, industrial, recreational etc.). Under MTCA, the total lifetime cancer risk from non-radiological contaminants is calculated at the $10^{-5}$ or $10^{-6}$ threshold depending on the future land use scenarios and the appropriate option (A, B or C) that are used.

If the MTCA approach is also used in calculating permissible residual radionuclide concentrations, the potential impact would be to reduce the effective dose limit to $0.5 \mathrm{mrem} / \mathrm{y}$ or lower and to lower the clean-up levels in soil and groundwater by at least an order of magnitude. This could potentially have significant cost and schedule impacts on the Hanford cleanup. In addition, measurement of radiological contaminants at the $10^{-6}$ threshold is orders of magnitude below the sensitivity of typical field survey instruments and is likely be technically impractical.

\section{Conclusions:}

The MTCA regulations do not specifically address radiological clean-up standards, however, the current precedent is for DOH (through the MOU with Ecology) to establish standards and oversee Ecology in the cleanup of radioactive wastes and facilities at Hanford. DOE, NRC, EPA and DOH have in general reached a consensus on using a $15 \mathrm{mrem} / \mathrm{y}$ dose limit to establish site cleanup levels. It is reasonable, therefore, to expect that the $15 \mathrm{mrem} / \mathrm{y}$ criteria currently being used to guide the Hanford cleanup will continue to be applicable. However, there has been no final resolution of this matter. The application of MTCA based procedures and standards is increasing for the Hanford cleanup in general and there is increasing pressure to use the more conservative MTCA risk based cleanup standards for the radiological as well as non-radiological contaminants. Thus, MTCA could potentially have a significant negative impact on the cost and schedule for cleanup of radiological contaminants at Hanford. 


\section{APPENDIX A.4}

\section{RISK ASSESSMENT}

Issue:

MTCA has various regulations requiring risk assessments to be performed in using use specified approaches except as provided for under sections 702 and 708 of MTCA. There are exceptions in the regulations to deviate from the default risk assumptions but Ecology must agree to the deviations. The burden of proof is on the person undertaking the cleanup action (or performing the risk assessment) if it is proposed to use other than the specified approaches. The exemptions available are: (a) use an alternative reasonable maximum exposure scenario other than the default; (b) use assumptions other than the default values; (c) establish a cleanup level under Method C; or (d) use a conditional point of compliance.

\section{Potential MTCA Impacts:}

MTCA specifies default values and methods to be used in performing risk assessments or calculating cleanup levels and remediation levels. Since the MTCA specified assumptions to calculate risks are more stringent than current risk assumption methodologies being used at Hanford; there is a possibility that lower clean-up levels (than currently assumed for Hanford cleanup) would result from using MTCA methodologies. In addition, potentially, past remedial/removal activities would have to be reevaluated with these new risk assumptions and more actions would have to be conducted at a site that was considered. Additional expenditure of resources to document and provide the justification to Ecology to use alternate risk methodologies and to negotiate exemption of past remedial/removal activities from reevaluation under MTCA.

\section{Current Risk Assessment Procedures:}

Cleanup levels and remediation levels are based on estimates of current and future resource uses and reasonable maximum exposures expected to occur under both current and potential future site use conditions. The reasonable maximum exposure is defined as the highest exposure that is reasonably expected to occur at a site under current and potential future site use. WAC 173-340$\underline{720}$ through 173-340-760 define the reasonable maximum exposures for ground water, surface water, soil, and air. These reasonable maximum exposures apply to most sites where individuals or groups of individuals are or could be exposed to hazardous substances. For example, the reasonable maximum exposure for most ground water is defined as exposure to hazardous substances in drinking water and other domestic uses.

Cleanup actions under MTCA can use the appropriate evaluation criteria in WAC 173-340-720 through 173-340-760 to demonstrate that the reasonable maximum exposure scenarios specified in those sections are not appropriate for cleanup levels for a particular site. Documentation for the use of alternate exposure scenarios is based on the results of investigations performed in accordance with WAC-173-340-350. Persons performing cleanup actions can also use alternate reasonable maximum exposure scenarios to help assess the protectiveness to human health of a cleanup action alternative that uses remediation levels, or engineered controls and/or institutional controls to limit exposure to the contamination remaining on the site. An alternate reasonable maximum exposure scenario reflects the highest exposure that is reasonably expected to occur under current and potential future site exposure. Land uses other than residential and industrial, 
such as agricultural, recreational, and commercial, are not used as the basis for a reasonable maximum exposure scenario for the purpose of establishing a cleanup level. However, these land uses may be used as the basis for an alternate reasonable maximum exposure scenario for the purpose of developing a remediation level. For example, if a cap (with appropriate institutional controls) is the proposed cleanup action at a commercial site, the reasonable maximum exposure scenario for assessing the protectiveness of the cap with regard to direct soil contact could be changed from a child living on the site to a construction or maintenance worker and child trespasser scenario.

\section{Proposed Revisions to MTCA:}

The proposed MTCA revisions attempt to clarify the use of a quantitative risk assessment in evaluating alternatives being considered during the feasibility study and in establishing cleanup levels (within specified constraints). Currently, Ecology uses mostly qualitative assessment of the residual risk. While the effect of using quantitative risk assessment will depend on site specific circumstances, Ecology generally anticipates higher levels of residual contamination.

Provisions allow the use of site-specific risk assessment in setting cleanup levels, remediation levels, or in making remedial action decisions under MTCA within certain limitations. This may result in an increase or decrease in cleanup levels and/or remediation levels (and subsequently costs) from the existing rule. There are a number of comments and unresolved technical and procedural issues regarding the proposed risk assessment provisions in MTCA. Specific DOE comments on the proposed revisions are provided in Appendix B. Some of the sections within MTCA with unresolved issues or needing clarification that pertain to using alternate site-specific risk calculations are listed below.

WAC 173-340-360 (12) (a) says risk assessments shall use specified approaches except as provided for under WAC 173-340-702 and 173-340-708

WAC 173-340-702 (12) (a) says the department shall determine the cleanup level (or risk assessment) that applies to a release based on the rules in effect at the time the final cleanup action for that release began or in effect when the department reviews the cleanup action, whichever is less stringent.

WAC 173-340-702 (14) places the burden of proof on the person undertaking the cleanup action (or performing the risk assessment) if it is proposed to (a) use a reasonable maximum exposure scenario other than the default; (b) use assumptions other than the default values; (c) establish a cleanup level under Method C; or (d) use a conditional point of compliance.

WAC 173-340-702 (15) says that Ecology shall consider new scientific information when establishing cleanup and remediation levels (or evaluating risk assessments). WAC 173-340-702 (16) states the criteria for quality of the information.

WAC 173-340-708 defines default values and methods to be used in performing risk assessments or calculating cleanup levels and remediation levels. Varying default values and methods is allowed under certain circumstances. When deciding whether to approve alternate values and methods the department shall ensure that the use of altemative values and methods will not significantly delay site cleanups. 
WAC 173-340-708 (3) (c) says the use of an alternate exposure scenario shall be documented by the person performing the cleanup actions (or performing the risk assessment) based on investigations performed in accordance with WAC 173340-350 (remedial investigation and feasibility study).

WAC 173-340-708 (7) and (8) say that the Reference Dose (RFD) and Cancer Potency Factor (CPF) for risk assessments for hazardous substances shall be those established by the EPA and available through the IRIS data base. Provisions are made for situations where IRIS may not have the information. Where a different RFD or CPF is established Ecology will provide the opportunity for public review and comment.

WAC 173-340-708 (10) Site specific measurable values of exposure parameters such as soil or hydrology characteristics can be changed. When different exposure parameter values are established Ecology will provide the opportunity for public review and comment.

\section{Conclusions:}

MTCA specified assumptions to calculate risks are more stringent than current risk assumption methodologies being used at Hanford and there is a possibility that lower clean-up levels and increased cleanup costs would result from using MTCA methodologies. There are exceptions in the regulations to deviate from the default risk assumptions but Ecology must agree to the deviations. The burden of proof is on the person undertaking the cleanup action (or performing the risk assessment) if it is proposed to use other than the specified. Furthermore, past remedial/removal activities would have to be reevaluated with these new risk assumptions and more actions would have to be conducted at a site that was considered. Potentially, additional expenditure of resources will be required to document and provide the justification to Ecology to use alternate risk methodologies and/or to negotiate exemption of past remedial/removal activities from reevaluation under MTCA. In light of the uncertainty and unresolved issues, conducting risk assessments under MTCA could potentially have a moderate negative impact on the cost and schedule for Hanford Cleanup. 


\section{APPENDIX A.5}

\section{TERRESTRIAL ECOLOGICAL EVALUATION PROCEDURES}

Issue:

The purpose of the draft Terrestrial Ecological Evaluation Procedures is to determine whether a release of hazardous substances to soil causes a threat to the terrestrial environment. The approach is to characterize the existing or potential threats to terrestrial plants or animals exposed to hazardous substances in soil and to establish site-specific cleanup standards for the protection of terrestrial plants and animals. Information collected during the evaluation will also be sued in developing and evaluating cleanup alternatives and selecting a cleanup action.

The goal of process is to protect terrestrial receptors from significant adverse effects which are defined as impacts that would significantly disrupt reproduction, feeding, sheltering, growth, or survival. The process requires that one of the following three evaluation methods be conducted at all waste sites: 1) document an exclusion from further ecological evaluation using the criteria provided in the draft; 2 ) conduct a simplified evaluation; or 3) conduct a site-specific evaluation using the procedures provided in the draft.

\section{Potential MTCA Impacts:}

The potential impact under MTCA of Ecology imposing any of these three methods would be a reduction of the calculated cleanup level by at least a factor of 10 with resulting significant increased cleanup costs. This could also effectively force the potentially liable person (i.e. Hanford) to use the established food web model provided in the draft rule even though it does not represent the local ecosystem.

\section{Discussion of Evaluation Methods:}

The point of compliance for the methods is set at the biologically active soil zone which is assumed to extend to a depth of 6 feet. An alternate depth may be approved by Ecology based on site conditions that consider the depth of soil macro-invertebrates; depth of soil turnover by invertebrates; depth of animal burrowing at the site; and depth of plant roots at the site.

Note: Tables 749-1 through 749-5 referenced in this section are from the most recent Ecology proposed rule revisions to MTCA (Washington State Department of Ecology, 1999)

1) Exclusion From Further Ecological Evaluation

An exclusion from an ecological evaluation may be obtained if:

- contamination is below 6 feet and an approved institutional control is in place; if contamination is below 15 feet, no institutional control is needed,

- the contaminated soil is or will be covered by buildings, roads, pavement, or other physical barriers that will prevent plants or wildlife from being exposed (institutional control is needed),

- there is less than 1.5 acres of contiguous undeveloped land within 500 feet of the contaminated site,

- there is less than 0.25 acres of contiguous undeveloped land within 500 feet of the contaminated site if specified organics are present, or 
- the concentrations of hazardous substances do not exceed background.

A site-specific ecological evaluation is required if the following criteria apply:

- the site is adjacent to a native or semi-native area,

- the site is used by threatened or endangered species, State "priority species," or "species of special concern,"

- the site is located within 500 feet of at least 10 acres of native vegetation, or

- if Ecology determines the site may present a risk to significant wildlife populations.

\section{2) Simplified Ecological Evaluation}

The simplified evaluation process is intended to identify those sites that do not pose a substantial threat to ecological receptors, and thus may be removed from further ecological consideration during the cleanup process. The evaluation process may be ended at a site when:

- the area of contamination is no more than 350 feet square,

- land-use makes wildlife exposure unlikely using exclusion criteria (see Table 749-1),

- there are no potential exposure pathways, or

- no hazardous substances listed in Table 749-2 are present or within 6 feet of the surface (institutional control required if contamination is within the top fifteen feet).

3) Site-Specific Ecological Evaluation

This section gives the procedures for conducting a site specific evaluation that will either determine that no treat to ecological receptors exists or facilitates the selection of a remedy that is protective of ecological receptors.

Planning a site-specific evaluation includes 2 steps that must be done in consultation with and approval by Ecology. They are problem formulation, and selection of one or more methods to address issues identified in the problem formulation.

Problem formulation includes:

- listing the chemicals of ecological concern by comparing contaminants present to Table 7493 in the draft rule,

- identifying complete exposure pathways,

- identifying current and future species and feeding guilds at the site and selecting those groups to be included in the evaluation,

- (consideration must be given to receptors most at risk and species that are protected under applicable state and federal laws),

- surrogate species for which greater information is available, or that are more suitable for the site may be used in the analysis,

- identifying significant adverse effects in receptors based on information from the literature.

\section{Selection of appropriate evaluation methods:}

If it is determined in the problem formulation step that further evaluation is necessary, the soil concentrations in Table 749-3 of the proposed revisions to MTCA may be used as the cleanup levels. Alternatively, one or more of the following methods may be used for a site-specific evaluation: 
- a literature survey to identify soil concentrations for chemicals not in Table 749-3; soil concentrations protective of plants or soil biota; or values for any or the wildlife exposure model values,

- soil bioassays using standard methods and approved by Ecology,

- wildlife exposure model using a generic food web and established parameters provided in Tables $749-4$ and 749-5,

- alternative values for established parameters, alternative receptor species of concern, alternative exposure pathways, and substitutions for receptors may be used provided they can be justified by an appropriate literature search and they are approved by Ecology,

- bio-markers may be used if shown to have clear relevance to the issues at the site,

- site-specific field studies to show no adverse effects to resident species,

- weight of evidence can be used to include a balance of literature, field and laboratory data, giving preference to site-specific data, or

- other methods approved by Ecology.

Directions are provided on what literature will be accepted and how its relevance will be judged. Also, provisions for accepting substitute species and associated values are provided. To account for uncertainties associated with the substitute receptors and parameters, Ecology may require the use of toxicity reference values based on no observed adverse effects; the use of uncertainty factors to account for extrapolations between species; and/or the use of a hazard index approach for multiple contaminants.

Provisions are made for Ecology to revise the hazardous substances and corresponding concentrations included in Table 749-2 when data indicate a significant tendency of the hazardous substance to persist, bio-accumulate, or be highly toxic to receptors.

\section{Effects on Hanford Cleanup:}

A comparison of the levels in Table 749-3 to the current cleanup levels for non-radiological Contaminants of Concern (COCs) in the Remedial Design Report/Remedial Action Work Plan for the 100 Area (DOE/RL-96-17, Rev. 1) is shown in Table 1.

The soil cleanup levels are primarily based on MTCA method B human health levels. Chromium VI, which is the exception, is based on a back calculation to soil from the federal freshwaterchronic Ambient Water Quality Criteria value of $11 \mathrm{ppb}$. Hanford Site background levels are provided where available for reference purposes.

There are three sources for the MTCA ecological indicator concentrations given in Table 749-3 of the MTCA proposed amendments. The plant values are based on benchmarks published in Toxicological Benchmarks for Screening Potential Contaminants of Concern for Effects on Terrestrial Plants: 1997 Revision, Oak Ridge National Laboratory, 1997. The soil biota values are based on benchmarks published in Toxicological Benchmarks for Potential Contaminants of Concern for Effects on Soil and Litter Invertebrates and Heterotrophic Process, Oak Ridge National Laboratory, 1997. The wildlife numbers were calculated using the exposure model provided in Table 749-4 and chemical -specific values provided in Table 749-5. Where both avian and mammalian values are available, the wildlife value is the lower of the two. Blank cells in the table apparently reflect a lack of information. 
Table 1. Comparison of Non-radionuclide COC cleanup levels to MTCA Ecorisk Levels in Table 749-3.

\begin{tabular}{|c|c|c|c|c|c|}
\hline \multirow[t]{2}{*}{ Contaminant } & \multicolumn{2}{|c|}{$\begin{array}{l}100 \text { Area Soil Cleanup Level } \\
(\mathrm{mg} / \mathrm{kg})\end{array}$} & \multicolumn{3}{|c|}{$\begin{array}{l}\text { MTCA Terrestrial Ecorisk Indicator } \\
\text { Concentration }(\mathrm{mg} / \mathrm{kg}) \text { from Table 749-3 }\end{array}$} \\
\hline & $\begin{array}{l}\text { Contaminant } \\
\text { Specific } \\
\text { Cleanup } \\
\text { Level }^{*}\end{array}$ & $\begin{array}{l}\text { Hanford } \\
\text { Background } \\
\text { Value }^{\text {b }}\end{array}$ & Plants & Soil Biota & $\begin{array}{l}\text { Wildlife } \\
\text { (Based on } \\
\text { MTCA } \\
\text { Foodweb } \\
\text { Model) }\end{array}$ \\
\hline Antimony & 6 & $\mathbf{N} / \mathbf{A}^{\mathbf{c}}$ & 5 & & \\
\hline Arsenic & 6.5 & 6.5 & & & 7 \\
\hline Barium & 5,600 & 13.2 & & & 102 \\
\hline Cadmium & 80 & N/A & 4 & & 14 \\
\hline $\begin{array}{l}\text { Chromium } \\
\text { III }\end{array}$ & 80,000 & \multirow[t]{2}{*}{$\begin{array}{l}\text { Total } \\
\text { chrome } 18.5\end{array}$} & \multirow{2}{*}{\multicolumn{3}{|c|}{ Total chrome (WA state background) 42}} \\
\hline Chromium IV & 2.2 & & & & \\
\hline Lead & $\mathbf{5 0 0}$ & 10.2 & $\mathbf{5 0}$ & & 118 \\
\hline Manganese & 11,200 & 512 & 1,100 & & 1,500 \\
\hline Mercury & 24 & $\mathbf{0 . 3 3}$ & Inorganic & $\mathbf{0 . 1}$ & 5.5 \\
\hline & & & Organic & & 0.4 \\
\hline Zinc & 24,000 & 67.8 & 86 & 200 & 360 \\
\hline $\begin{array}{l}\text { Polychlorinat } \\
\text { ed Biphenals }\end{array}$ & 0.13 & N/A & & & 0.65 \\
\hline $\begin{array}{l}\text { Benzo(a)pyre } \\
\text { ne }\end{array}$ & 0.33 & N/A & & & 12 \\
\hline $\begin{array}{l}\text { Pentachlorop } \\
\text { henal }\end{array}$ & 8.33 & $\mathbf{N} / \mathbf{A}$ & 3 & 6 & $\overline{4.5}$ \\
\hline
\end{tabular}

"Value from Table 2-7 in DOE/RL-96-17 Rev.1

${ }^{b}$ Value from Table 2-1 in DOE/RL-96-17 Rev.1

${ }^{c}$ Not available

Inspection of the table shows that, for 9 of the 13 contaminants listed in the table, one or more of the MTCA values from the Table 749-3 is lower than the existing soil cleanup levels for those contaminants. The question is whether concentrations greater than the MTCA values represent potential threats to existing Hanford biota.

\section{Conclusions:}

There are a number of technical and procedural comments and issues associated with the draft Terrestrial Ecological Evaluation Procedures. In addition to the discussion presented here there are a series of DOE comments to Ecology regarding these draft procedures in Appendix B. The result of Ecology imposing any of the conservative measures in the draft procedures (as shown in Table 1) would be a reduction of the calculated cleanup level by at least a factor of 10 and a resulting significant increase in Hanford cleanup costs. The draft Terrestrial Ecological Evaluation Procedures in Ecology's proposed revision to MTCA represents a potentially significant negative impact on cost and schedule for Hanford cleanup. 


\section{APPENDIX A.6 \\ REMEDY SELECTION}

Issue:

To select a remedy under the Model Toxics Control Act (MTCA), Washington Administrative Code (WAC) 173-340, specifically WAC 173-340-360, a state remedial action and feasibility study (RI/FS) must be completed as required by WAC 173-340-350. The only exception to selecting a remedy in the absence of a RI/FS is for an emergency or interim action. An interim action is a remedial action that partially addresses the cleanup of a site.

In WAC 173-340-360(13), (WAC 173-340-380(4) in the proposed revision to MTCA), a ROD or order or consent decree prepared under the Federal Cleanup Law (i.e. CERCLA/RCRA), that provides for a cleanup action, may be used by the department to meet the requirements of this section provided:

1. The cleanup action meets the threshold and other requirements described in WAC 173-340-360(2) and WAC 173-340-360(3);

2. Ecology concurred with the cleanup action; and

3. An opportunity for public comment was provided on the cleanup action.

The proposed revisions to MTCA, WAC 173-340-350(8)(c )(ii)(B), also specify that a cleanup action shall not be considered practicable if the incremental cost of the cleanup action selected is "substantial and disproportionate" to the incremental degree of protection it would achieve over a lower preference cleanup action.

\section{Potential MTCA Impacts:}

The MTCA RI/FS process is similar to the CERCLA/RCRA process at Hanford. Some of the procedures could result in increased costs and some are potentially more efficient and less costly. Overall little or no impact from the MTCA remedy selection process is currently anticipated although the imposition of any new process generally results in some increased documentation and administrative costs.

The current and proposed MTCA rules are not entirely clear regarding the relationship between MTCA and federal cleanup actions. There is concern that, potentially, MTCA would require revisiting past or ongoing federal cleanup actions at Hanford to impose stricter methods for determining cleanup levels and remedy selection. Although the rules appear to preclude this, clarification on this point is needed.

The proposed revision to MTCA also allows for the demonstration of "substantial and disproportionate" costs when choosing not to select a more expensive and permanent remedy. However, this section is vague and no criteria are provided for this demonstration. Potentially additional time and resources would be required to resolve disagreements between DOE and Ecology over the demonstration of "substantial and disproportionate" costs. 


\section{State Remedial Investigation and Feasibility Study Process:}

The state RI/FS process is similar, but not an exact replica, to the federal RU/FS described in 40 Code of Federal Regulations (CFR) 300.430. 40 CFR 300.430 implements the superfund program, also known as the Comprehensive Environmental Response, Compensation, and Liability Act (CERCLA). WAC 173-340-350 describes the required RI/FS information in eight different categories. Those categories are: 1) General facility information, 2) Site conditions map, 3) Field investigations, 4) Risk assessment, 5) Cleanup action alternatives, 6) Work plans, 7) Treatability studies and, 8) State Environmental Policy Act (SEPA) information. Each category lists specific information necessary and comparing this information directly to 40 CFR 300.430 yields slight differences in required information, mainly SEPA information. This can be further evaluated. However, WAC 173-350(5) states "for facilities on the federal national priorities list, the state remedial investigation/feasibility study shall comply with federal requirements." This critical point ensures the RI/FS documentation process would not change if MTCA were the sole authority for the 100 Area, 200 Area, and 300 Areas of the Hanford Site. These areas are on the National Priorities List (NPL). The 1100 Area was deleted from the NPL on September 30, 1996.

\section{Remedy Selection Requirements}

The state remedy selection is described in WAC 173-340-360 and specifies the criteria for approving cleanup actions, the order of preference for cleanup technologies, policies for permanent solutions to the maximum extent practicable, and must be used in conjunction with cleanup standards specified in WAC 173-340-700 through WAC 173-340-760.

Each remedy selected under MTCA must comply with four threshold requirements and those are the following: 1) Protect human health and the environment, 2) Comply with cleanup standards contained in WAC 173-340-700 through WAC 173-340-760, 3) Comply with applicable state and federal laws and, 4) Provide for compliance monitoring. Additional requirements, not qualified as threshold requirements, include the following: 1) Use permanent solutions to the maximum extent practicable, 2) Provide for a reasonable restoration timeframe and, 3) Consider public concerns during public comment.

In CERCLA, 40 CFR 300.430(e)(9)(iii) compares each remedy (alternative) to nine criteria. These criteria fall into three categories. 1) Threshold, 2) Balancing and, 3) Modifying. The first two criteria [Overall Protection of Human Health and the Environment, and Compliance with Applicable or Relevant and Appropriate Requirements (ARARs)] are considered threshold criteria and must be met for each remedy to be further evaluated. ARARs are applicable or relevant and appropriate laws/regulations (state, federal, local), orders, and/or guidance. The next five criteria are considered balancing criteria and are used to compare technical and cost aspects of the alternatives. The final two criteria (State Acceptance and Community Acceptance) include: 1) Destruction or detoxification: 2) Separation of volume reduction followed by reuse, recycling, destruction, or detoxification of the residual hazardous substance: and 3) Immobilization of hazardous substances. On-site or off-site disposal at an engineered considered modifying criteria and are to be considered in selecting the remedy. The threshold criteria of CERCLA and MTCA contain no difference in requirements.

\section{Order of Preference for Cleanup Technologies}

MTCA has other requirements such as the cleanup technologies selected to implement the remedy must be evaluated using a hierarchy before the specific technology is accepted. WAC 173-340-360(4)(a) states the following technologies shall be considered in order of descending 
preference: 1)Reuse or recycling facility; 2)Isolation or containment with attendant engineering controls; and 3)Institutional controls.

This hierarchy is not explicit in 40 CFR 300.430(e)(3)(i) or 40 CFR 00.430(e)(9)(iii)(D). However, 40 CFR 300.430(e)(9)(iii)(D) does contain specific language that states "The degree to which alternatives employ recycling or treatment that reduces toxicity, mobility, or volume shall be assessed, including how treatment is used to address the principal threats posed by the site." The federal regulations do not list a hierarchy and this is a major difference between MTCA and 40 CFR 430. If MTCA were the sole authority, the documentation necessary to justify and support a specific technology selected to implement the remedy could be more extensive than our current documentation. This could increase the time necessary for reaching decisions. WAC $173-340-360(4)(d)$ states "The adoption of the technology preferences in this subsection is designed to make it more difficult to select a cleanup action with a low preference without careful explanation of why technologies above it have not been used."

\section{Permanent Solutions to the Maximum Ertent Practicable}

Remedies selected under MTCA shall be "permanent to the maximum extent practicable." To evaluate whether a remedy is permanent, seven criteria must be evaluated as described in WAC 173-340-360(5)(d). Those seven criteria are the following: 1) Overall protection of human health and the environment, 2) Long-term effectiveness, 3) Short-term effectiveness, 4) Permanent reduction of toxicity, mobility and volume of the hazardous substance, 5) Ability to be implemented, 6) Cost and, 7) Degree to which community concerns are addressed.

These criteria are similar to the criteria described in 40 CFR $300.430(e)(9)($ iii). The only difference is that WAC 173-340-360(5)(vi), Cleanup cost, specifies that a cleanup action shall not be considered practicable if the incremental cost of the cleanup action selected is "substantial and disproportionate" to the incremental degree of protection it would achieve over a lower preference cleanup action. The method for demonstrating substantial and disproportionate costs is not clearly presented in the current proposed revision to MTCA. There are a number of DOE comments on this subject in Appendix B.

Both 40 CFR 300.430 and MTCA have cost criteria. 40 CFR 300.430 only specifies the "types of costs" that shall be assessed, which is direct capital cost, indirect capital cost, annual operation and maintenance $(O \& M)$ cost, and net present value of capital and $O \& M$ costs. WAC 173-34$360(5)$ (vi) does not contain this information. If MTCA were the sole authority, there could be an ability to better utilize the substantial and disproportionate concept to demonstrate when two remedies that provide equal protection but differ is cost, the lower cost remedy is selected. Should the resources (time, money) to develop the demonstration be greater than the difference in the cost of the two remedies, there is no benefit. Consideration of this point would be necessary.

\section{Restoration Time Frames}

Implementation of remedies selected must provide for a reasonable restoration time frame as described in WAC 173-340-360(6). This section requires evaluation of nine factors in developing a reasonable time frame and are the following: 1) Potential risks to human health and the environment, 2)' Practicability of achieving a shorter time frame, 3) Current use of the site, surrounding areas, and resources, 4) Potential future use of the site, surrounding areas, and resources, 5) Availability of alternative waster supplies, 6) Effectiveness and reliability of institutional controls, 7) Ability to control and monitor migration of hazardous substances, 8) Toxicity of hazardous substances at the site and, 9) Natural processes which reduce 
concentrations of hazardous substances. However, extending the time frame shall not be used as a substitute for active cleanup, if cleanup actions are practicable.

These restoration time frame factors are not contained in 40 CFR 300.430 . The only time factor in 40 CFR 300.430 related to remedy selection is in 40 CFR 300.430(f)(4)(ii), which states if a remedial action is selected that leaves hazardous substances, pollutants, or contaminants above levels that allow for unlimited use and unrestricted exposure that the cleanup action will be reviewed at least every five years. The U.S. Environmental Protection Agency (EPA) refers this as the "5 Year Review." Guidance by EPA is expected in April 2000. MTCA does require a five-year review as described in WAC 173-340-420, and lists specific factors to evaluate the cleanup action.

If MTCA were the sole authority, the Washington State Department of Ecology (Ecology) could have a larger role in determining the schedules (restoration time frame) for cleanup, rather than the contractor and U.S. Department of Energy, Richland Operations Office (RL). Both MTCA and 40 CFR 300.430 require a schedule, and EPA and Ecology have primarily supported the schedule developed by RL and the contractor. Additionally, the language in WAC 173-340360(6) could give more authority to Ecology in determining an appropriate schedule, and in the absence of EPA and 40 CFR 300.430, unreasonable schedules could be imposed and not attainable. Implications of this situation could be severe in terms of penalties and missed milestones. EPA and Ecology have issued many cleanup orders to the Hanford Site, and a schedule is contained in the Remedial Design/Remedial Action (RD/RA) work plan, which is required within 15 months following the Record of Decision (ROD). Schedule development to date has been reasonable, and EPA and Ecology have not been critical in the time frames established.

\section{Cleanup Action. Plan}

WAC 173-340-360(10) states the department (Ecology) shall issue a draft cleanup action plan for cleanups conducted by Ecology or a potentially liable person under an order or decree. 40 CFR 300.430 calls this plan a "Proposed Plan." If MTCA were the sole authority, a cleanup order or decree would be issued to RL. Currently, RL is issued a ROD, signed by Ecology and EPA, and RL signs for concurrence. The legal differences between a ROD and a cleanup order or decree issued by Ecology would need legal council review and analysis.

Public comment processes and requirements are similar to 40 CFR 300.430. However, the Hanford Federal Facility Agreement and Consent Order, commonly referred to as the Tri-Party Agreement (TPA) outlines community relations and public involvement requirements in Section 10. If MTCA were the sole authority, the TPA, Section 10, may require revision to delete references to CERCLA and modify the mailing list requirements. WAC 173-34-600(3)(b) requires a notice be mailed to persons who reside within the potentially affected vicinity, which includes all property adjoining the site. This requirement is not a current practice and, if implemented, could significantly raise public involvement cost. Secondly, WAC 173-340-600(4) requires a public meeting if ten or more people request a public meeting. This requirement is not explicit in the TPA or 40 CFR 300.430 , and, if implemented, could significantly raise public involvement cost and require TPA modifications.

\section{Relationship to past and future CERCLA/RCRA cleanup actions at Hanford:}

WAC 173-340-360(13) states that a ROD or order or consent decree prepared under the "Federal Cleanup Law that provides for a cleanup action may be used by the department to meet the requirements of this section provided:" 
1. The cleanup action meets the threshold and other requirements described in WAC 173-340-360(2) and WAC 173-340-360(3);

2. Ecology concurred with the cleanup action; and

3. An opportunity for public comment was provided on the cleanup action.

If MTCA were the sole authority, Ecology could not revisit the existing cleanup actions issued by EPA to date based on the criteria listed above. Ecology has signed each ROD issued and public comment was solicited in each cleanup action.

The MTCA revisions should be modified to state that a federal cleanup action will be deemed to satisfy the requirements of MTCA provided that the cleanup action incorporates and complies with the substantive provisions of MTCA, as acknowledged by Ecology signature on the decision document for the CERCLA cleanup action. This would eliminate the jeopardy faced by potentially responsible parties of completing an approved cleanup action under the federal cleanup law only to face the possibility of a subsequent cleanup action imposed pursuant to MTCA. This concept could be included in the MTCA regulations by making changes to the language proposed in WAC 173-340-380(4). See comment (4) on page 3 of Appendix B.

For future cleanup actions still needing decisions and assuming MTCA is the sole authority, an interpretation of WAC 173-340-360(13) could provide that federal cleanup orders (RODs) could still be issued at Hanford provided the site in listed on the Federal NPL. This would need a further evaluation by legal council.

\section{Containment Remedies:}

WAC 173-340-360(5)(c) and WAC 173-340-360(8) contain strict language on the application of containment remedies. For a remedy to employ a cap, the language in WAC 173-340-360(5)(c) states "Containment of hazardous substances and/or institutional controls alone are not permanent solutions." Second, WAC 173-340-360(8)(c) states that if a proposed cleanup action involves onsite containment that the cleanup action plan shall specify the types, levels, and amounts of hazardous substances remaining on-site. If MTCA were the sole authority, the application of a cap could be more burdensome in the justification and more costly in characterization.

\section{Flexibility:}

Although WAC 173-340-360 contains strict requirements and language in various sections, there is flexibility provided in other sections such as WAC 173-340-360(4)(b), WAC 173-34360(4)(d), WAC 173-340-360(5)(d), and WAC 173-340-360(9)(c).

\section{Conclusions:}

The MTCA RI/FS procedures are similar to those in the Federal Cleanup Law (CERCLA) and in RCRA. There are, however, a number of technical and procedural comments that are still unresolved. DOE comments to Ecology relating to the remedy selection process in the proposed revision to MTCA are provided in Appendix B. Despite the comments and unresolved issues, remedy selection under MTCA will most likely have little or no impact on cost and schedule for Hanford cleanup. 


\section{APPENDIX A.7}

\section{LAND USE ASSUMPTIONS}

Issue:

MTCA provides for different cleanup levels depending on current and future site use. The most restrictive cleanup levels defined under MTCA are based on assumptions of residential use. However, the current revision of MTCA also defines cleanup levels that would support industrial use, and contains flexibility to develop cleanup levels for other site uses on a case-by-case basis. Some members of the Ecology staff have indicated that the use of an exposure scenario other than residential use requires property to be zoned under the state's Growth Management Act (GMA). The Hanford Site does not meet the requirement because it is not subject to local zoning ordinances and DOE's land use plans (i.e., the Comprehensive Land-Use Plan EIS and Record of Decision) are not adopted under the GMA. Thus, Ecology believes that, statutorily, MTCA industrial soil cleanup levels cannot be applied.

Impact:

Under Ecology's interpretation, the 200 and 300 Areas would need to be remediated to MTCA residential use cleanup levels. This could be at least one order of magnitude more stringent than the industrial cleanup levels.

\section{What MTCA says}

WAC 173-340-745(1)(b) establishes criteria for industrial land use. The first criterion is that a site must meet the following definition of "industrial property" in WAC 173-340-200:

"Properties that are or have been characterized by, or are to be committed to, traditional industrial uses such as processing or manufacturing of materials, marine terminal and transportation areas and facilities, fabrication, assembly, treatment, or distribution of manufactured products, or storage of bulk materials, that are either:

- Zoned for industrial use by a city or county conducting land use planning under chapter 36.70A RCW (Growth Management Act); or

- For counties not planning under chapter 36.70A RCW (Growth Management Act) and the cities within them, zoned for industrial use and adjacent to properties currently used or designated for industrial purposes.

See WAC 173-340-745 for additional criteria to determine if a land use not specifically listed in this definition would meet the requirement of "traditional industrial use" and for evaluating if a land use zoning category meets the requirement of being "zoned for industrial use.""

The second bullet in the definition allows a site to be identified as an "industrial property" without planning under the GMA, so the point made by Ecology staff is not quite true. To determine if a property is "zoned for industrial use," WAC 173-340-745(b)(i) says the following shall be considered: people do not normally live on industrial property; access by the general public is not normally allowed; food is not normally grown; industrial properties are often characterized by chemicals, noise, odors, and truck traffic; the surface of the land is often covered 
by buildings, paving, etc. that minimize potential exposure to soil; support facilities (offices, restaurants, etc.) are primarily for industrial employees, not the public.

In other parts of the regulation, WAC 173-340-740(1)(a) states that soil cleanup levels shall be based on residential site use unless the site does not serve as a current residential area and does not have the potential to serve as a future residential area. WAC 173-340-740(1)(d) states that "soil cleanup levels for other non-residential site uses such as recreational or agricultural will be established on a case-by-case basis."

The proposed MTCA revisions include the same definition of "industrial properties." However, the revision would add a definition for "conducting land use planning under chapter 36.70A RCW so that it "means having adopted a comprehensive plan and development regulations for the site under chapter $36.70 \mathrm{~A} \mathrm{RCW}$

\section{Other discussion points:}

- The Comprehensive Land-Use Plan EIS presents the preferred land use plans for various entities, including local governments. An industrial land use within the 300 Area is consistent with the land use identified by Benton County and the City of Richland, both of which perform land use planning in accordance with the GMA.

- EPA and Ecology have accepted "industrial use" as the cleanup basis for waste sites in the 300 Area in the 300-FF-1 and 300-FF-5 CERCLA Record of Decision.

- The Comprehensive Land-Use EIS defines future use of the 200 Area as "waste management." This is not a specific use defined in MTCA, but most closely aligns with industrial use.

\section{Conclusions:}

Future land use assumptions are an essential part of determining cleanup levels at Hanford. In particular an industrial classification for future land use at Hanford is key to arriving a reasonable remedy selection and cleanup levels. The current and proposed MTCA requirements are not entirely clear on the criteria for allowing the "industrial classification," although it appears that the industrial classification is appropriate. This issue, however, has not been resolved between DOE and Ecology and the proposed revisions to MTCA do not add any clarity to the issue. Under MTCA, if a residential rather that industrial land use scenario is mandated then there will be significant negative cost and schedule impacts to the Hanford cleanup. 


\section{APPENDIX A.8 \\ MTCA PRACTICES AROUND THE STATE}

Issue:

In a review of cleanup decisions around the State of Washington, it can generally be stated that the application of MTCA to State cleanup decisions is occurring within the flexibility provided for in regulation. For example, containment is being chosen where appropriate. For landfills, containment was consistently chosen as the selected remedy. For industrial areas, containment in the form of asphalt or concrete is widely selected. The use of groundwater protection levels was deemed to not apply in areas where groundwater was not intended to be used for drinking water purposes in the foreseeable future. Institutional controls/monitoring are being used where contaminants will remain. Below are some examples of cleanup decisions around the State. These examples were selectively chosen to illustrate the flexibility in the application of MTCA and are not necessarily a cross-section of remedies chosen throughout the State. Key statements are italicized for emphasis.

\section{Cleanup Actions where Containment is the Selected Remedy}

The attached Table 1 lists sites around Washington that have CERCLA Records of Decision citing containment as a selected remedy. Current MTCA requirements allow containment as a cleanup option. Regulations contained in WAC 173-340-740(6)(d) state: "The department recognized that, for those cleanup actions selected under WAC 173-340-360 that involve containment of hazardous substances, the soil cleanup levels will typically not be met at the points of compliance specified in (b) and (c) of this subsection [groundwater and direct contact pathways, respectively]. In these cases, the cleanup action may be determined to comply with cleanup standards, provided the compliance monitoring program is designed to ensure the longterm integrity of the containment system, and the other requirements for containment technologies in WAC 173-340-30(8) are met." This allowance is without regard to the exposure scenario (MTCA Method B or C) contemplated as evidenced by Containment remedies chosen within many differing land use scenarios within the State of Washington.

Everett Smelter Site (ASARCO) - At this site, arsenic contamination will be removed in areas of high concentration and consolidated within a fenced area. Inaccessible contaminated soil that will be "contained" beneath existing permanent structures and pavement will be left in place. At these areas, institutional controls will be instituted. Contingency plans will be developed that will require additional cleanup actions if monitoring indicates that cleanup is not meeting goals.

Downtown Seattle Gasworks Park - Ecology determined that contact with underlying soils could result in unacceptable risks to Park users. Excavation and treatment of material to a depth of 15 feet was determined to be technically impracticable. The cleanup decision was to prevent direct contact with contamination (PAHs and heavy metals) by application of containment technologies and institutional controls. The proposed cleanup action for the Park includes placing a new vegetated soil cover over unpaved open areas in the north-central and southeastern portions of the Park. The soil cover will serve as a protective barrier between Park users and chemicals of concern.

The groundwater at the western portion of the Park is contaminated with PAHs (including carcinogenic PAHs). Natural attenuation is reducing the concentrations of these chemicals to surface water cleanup criteria prior to their discharge into Lake Union. The City and Puget Sound Energy will be required to demonstrate that attenuation is actually occurring at a rate sufficient 
to meet surface water criteria within a reasonable restoration time frame. The effectiveness of attenuation as a remedial action will be evaluated during the first periodic review. Should attenuation not be progressing as anticipated, other more active remedial actions may be required.

ARCO Terminal 21T Harbor Island Site - Seattle - The goal of soil cleanup standards and action levels for petroleum hydrocarbons at this site is to protect the beneficial use of groundwater (surface water quality and associated ecosystem) and to contain residual contamination within property boundaries. The site is currently an "industrial" site and is anticipated to be zoned and used as an industrial site in the foreseeable future. The proposed cleanup action for the site includes the implementation and maintenance of institutional controls to prevent future human exposure to the currently inaccessible constituents located under a warehouse) present in the soll (including vapors) and groundwater beneath the Terminal. ARCO will add a restrictive covenant to the property to restrict the property use to industrial purposes or interfering with remedial actions implemented.

GATX Terminal Corporation Harbor Island, Seattle - Ecology and EPA have determined that there is no current or planned future use of groundwater beneath Harbor Island for drinking water purposes. Groundwater cleanup levels were determined by Ecology to be surface water standards that are protective of aquatic organisms in Elliott Bay. The decision does not require that groundwater meet drinking water standards or more stringent calculated MTCA groundwater protection values.

NORTAR/Former ATCO Facility at 1700 North Northlake Way, Seattle - As with GATX, surface water cleanup levels are proposed for groundwater because groundwater beneath this site is not considered to be potable at this site's surface water discharge point, Lake Union.

Thea Foss Waterway in Tacoma - At this site, the preferred cleanup will include covering contaminated soil with a pavement cap or soil cover in the form of new roadway pavement, sidewalks, and parking area. As part of the utility installation/relocation, some contaminated soil will be removed where particularly high levels of contamination exist at levels above remediation action levels established for the site. Institutional controls will be implemented to control future excavation, provide for long-term maintenance of the cap/cover, and potentially provide for routine environmental monitoring. 


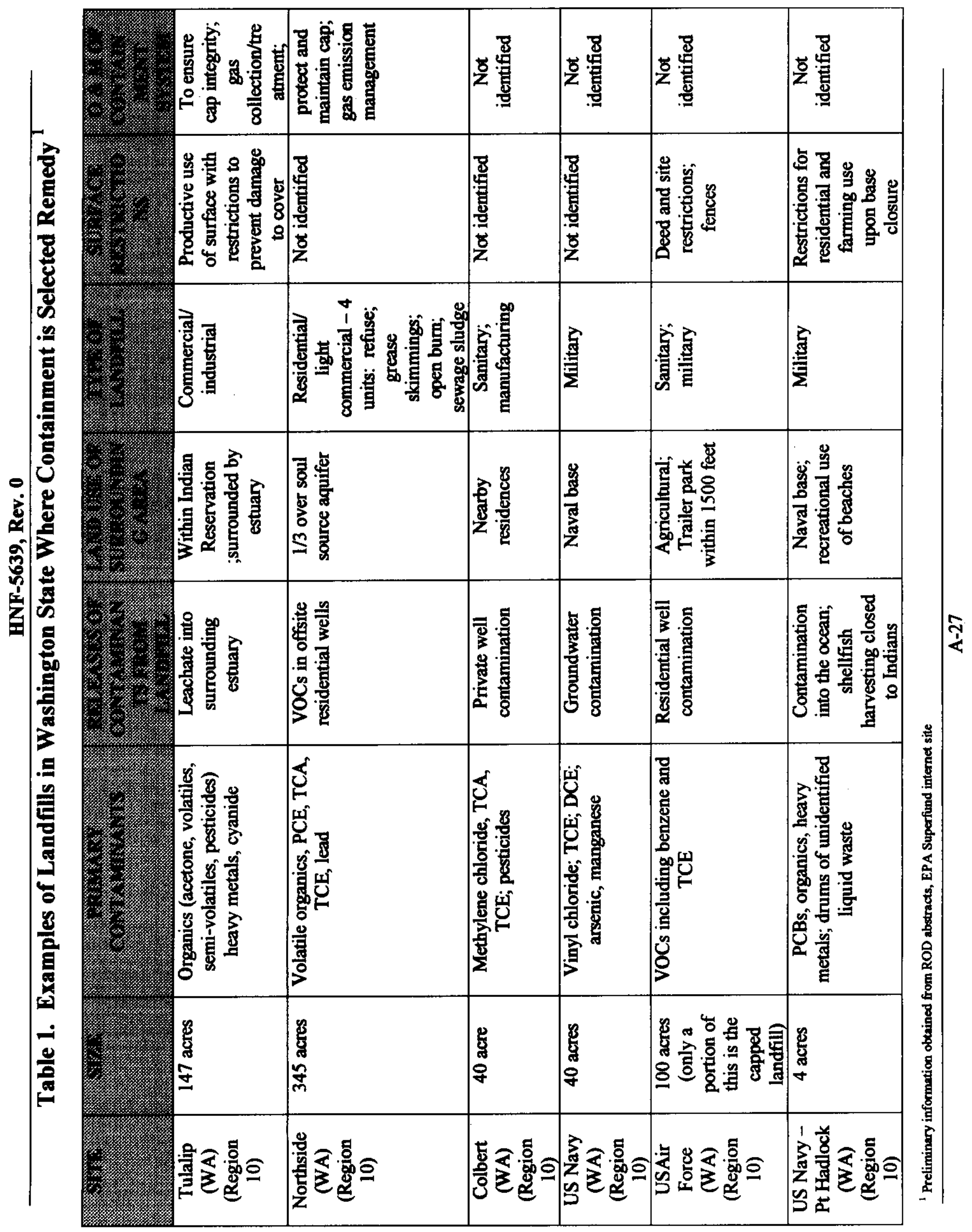




\section{APPENDIX A.9}

\section{ASSOCIATION OF WASHINGTON BUSINESS (AWB) POSITION ON MTCA}

The Association of Washington Business (AWB) has been involved in reform of the Model Toxics Control Act (MTCA) regulation since the beginning. They were instnumental in bringing concerns Washington businesses had with MTCA to the legislature in 1995 which ultimately led to the enactment of Engrossed Substitute House Bill 1810 (Bill) to reform MTCA. This Bill directed Ecology to establish a 22 member Policy Advisory Committee (PAC) composed of representatives from the business community, environmental organizations, local governments, port districts, the Science Advisory Board, legislature, and state agencies to review, provide advice and develop recommendations to amend the MTCA rule. The PAC met numerous times over the course of six months and on December 15, 1996, presented Ecology and the legislature with a report entitled, "Final Report of MTCA Policy Advisory Committee", which contained their recommendations for regulatory changes to MTCA.

Once the report was issued, Ecology began rulemaking. As part of the process, in early 1997, they convened the MTCA External Advisory Committee (Ecology Committee) which was composed of representatives of the business community, environmental organizations, ports, and local governments some of whom were members of the PAC to provide advice to Ecology on amending MTCA. At the same time, the AWB formed its own committee, the AWB MTCA Workgroup (AWB Workgroup), to evaluate MTCA. An FDH representative participated in both forums. Ecology met with the Ecology Committee several times over the course of a year and in February 1998, issued a discussion draft amended MTCA rule. AWB as well as individual businesses responded with numerous comments voicing their disappointment and concerns with the draft particularly those sections on ecological risk, remedy selection, point of compliance, land use, soil to ground water pathways, total petroleum hydrocarbons and risk assessment. AWB felt that there were some significant issues that Ecology hadn't addressed. Ecology responded to this by hiring a contractor, Landau and Associates, to facilitate resolution of these issues. They also encouraged stakeholders to draft altemative rule language.

As a result, the AWB Workgroup wrote their own version of the MTCA rule and submitted it to Ecology in June 1997. At the same time AWB submitted their rule, Ecology released a second MTCA draft for stakeholder review and comment. Ecology then handed both of these to the facilitator who used them as the basis for discussions to resolve the outstanding issues. Several AWB Workgroup members were involved in meetings with the facilitator, Ecology's senior management as well as mid-level management in the Toxic Cleanup Program, and members of the environmental community to negotiate rule language that would address businesses concerns. The meetings were held over the course of several months and at the end of the process AWB felt they had reached agreement with Ecology and the environmental community on several key points.

Once these meetings were complete, Ecology began preparing a 3rd draft of the rule, which became the proposed rule that was published in the Washington State Register on November 17, 1999. At the same time, they released the Small Business Economic Impact Statement, the Ecological Risk Pilot Project, and the MTCA Rule Amendment Environmental Impact Statement.

On November 30,1999, the AWB Workgroup met to discuss their concerns with the proposed rule plus other documents and to develop a strategy on what to do next. At that meeting, the members expressed concern that not only did Ecology not follow through on their agreements 
that members felt they had reached with them on certain key points in previous meetings but had also not followed through on certain of the PAC recommendations, particularly, the recommendations on remedy selection, total petroleum hydrocarbons, and risk assessment. In addition, the AWB members felt that Ecology had also failed to follow through on the standards the agency had set for itself for the rulemaking which were to make the rule fairer, easier to understand, more flexible, less ambiguous and less expensive. This failure was apparent in the provisions on soil cleanup levels to protect ground water, human health risk assessment, ecological risk evaluation, remedy selection, independent cleanups, institutional controls, petroleum cleanups, and the grandfather clause. Finally, they want to see the rule delayed in order that the key areas that are still of major concern to businesses can be addressed.

A strategy was then developed to determine how best to do this. Several options were discussed including meeting with Ecology's senior management to voice businesses concerns and asking them to withdraw the rule; nunning a bill through the legislature to get a moratorium; applying legislative pressure; and appealing it through the legal system.

After discussing each option, AWB members determined that the best strategy is as follows:

- AWB will submit comments for its members and at the same time individual businesses will deluge Ecology with comments plus send a copy of their comments to their respective legislators;

- AWB will meet with key legislators during the next legislative session to get them to put pressure on Ecology to delay the rule and at the same time individual members will voice their dislike of the proposed rule with their respective legislators;

- AWB will talk to legislators about holding a hearing during the next legislative session at which Ecology would be invited to testify on the rule and at the same time individual members will talk to their respective legislators on holding a hearing;

- AWB will set up a meeting with Ecology senior management to voice businesses concerns with the rule and get them to delay it while they work with business to resolve these outstanding issues;

- AWB and individual members need to identify the top winning arguments and articulate those in a simple way in their comments to Ecology and to their legislators.

AWB members decided not to pursue introducing a Bill to put a moratorium on the rule or to take legal action at this time but will reevaluate these options should the above strategy not work. 


\section{REFERENCES}

U.S. Department of Energy, 2000, Hanford Site Comments On Proposed Changes to Model Toxics Control Act Cleanup Regulation, Submitted to the Washington State Department of Ecology, January 2000. Included in this document as Appendix B.

Washington Department of Ecology, 1999, Proposed Rule Revision for Model Toxics Control Act (Chapter 173-340 WAC), Original Notice, WSR-99-22-077, filed November 2, 1999.

Washington Department of Health, 1997, Hanford Guidance for Radiological Cleanup, WDOH/320-015, Rev 1, November 1997.

Washington Department of Health, 1994, Memorandum of Understanding Between the Washington State Department of Ecology and the Washington State Department of Health.

Washington Department of Ecology, 1996, The Model Toxics Control Act Cleanup Regulation, Chapter 173-340 WAC, Amended January 1996, Publication No. 94-06.

Gilbert, R. O. and J. C. Simpson, 1992, Statistical Methods for Evaluating the Attainment of Cleanup Standards, Volume 3: Reference-Based Standards for Sotls and Solid Media, PNL-7409 Vol. 3, Rev. 1, Pacific Northwest National Laboratory, Richland, Washington. 
HNF-5639, Rev. 0

APPENDIX B

HANFORD SITE COMMENTS ON PROPOSED CHANGES TO

MODEL TOXICS CONTROL ACT CLEANUP REGULATION

B-1 


\title{
HANFORD SITE COMMENTS ON PROPOSED CHANGES TO MODEL TOXICS CONTROL ACT (MTCA) CLEANUP REGULATION
}

\author{
General Issues
}

1. Rule development process: The Washington State Department of Ecology (Ecology), the regulated community, and numerous public interest groups have spent a good deal of time and effort on this MTCA rulemaking endeavor. Ecology's dissemination of the pre-proposal draft version of the rule changes in late 1998 presented a valuable opportunity to consider the adequacy of the contemplated changes. Ecology received a large number of significant comments from various quarters. These comments identified a number of serious concerns with the rulemaking language. Although Ecology has revised the proposed rule in an attempt to address these issues in large measure, many of the concerns raised on the draft still remain. As a consequence, many of the comments presented below are similar to comments previously submitted, and which RL believes have not yet been adequately addressed.

2. Overall evaluation: Contrary to Ecology's desired intention, as stated in a cover sheet, publication \#98-605, included with the December 1998 draft rule, that this proposed rule will make the business of environmental cleanups fairer, easier to understand, more flexible, less ambiguous and less expensive, the proposed MTCA rule clearly does not satisfy these criteria. For instance, on the criteria of:

Fairness. Ecology has added new requirements for providing notice to local government and nearby property owners that is over and above the existing public notice requirements and at the discretion of Ecology personnel. It has also included new language in the independent cleanup section, which gives the agency unrestricted control over these types of cleanup by requiring all releases and independent cleanups to be reported. Additionally, while the ecological risk assessment provisions allow for substitute receptor species, Ecology has included a catchall statement which will basically force the potentially liable person to comply with Ecology's food-web model if the agency doesn't like the substitute values or species proposed. Finally, Ecology does not satisfy the criteria of faimess when it concludes in the Small Business Economic Impact Statement that there will be a disproportionate impact on small businesses.

Easier to understand. Although Ecology has reorganized the remedy selection provisions, this has not helped to clarify what is intended and in fact the provisions in the proposed rule represent a great reduction in clarity and readability from the current rule. Also, the soil to ground water provisions are so technically involved as to be unreadable, therefore, clearly not satisfying the criteria that the proposed rule is "easier to understand".

Flexible. While Ecology has provided options in risk management, such as "natural attenuation", there is no guidance on how to use this or the other options which takes away from the ability of the potentially liable person (plp) to have flexibility. Furthermore, we are concerned that Ecology will not be able to provide guidance in the near future which will make it difficult for the plp to take advantage of these options. Also, Ecology has provided more options for risk assessment but these are difficult to find in the text. 
Less Ambiquous. Ecology has created ambiguity by not including a description of how to do a disproportionate cost analysis. Also, there is ambiguity in the ecological risk assessment provisions, as state above, wherein Ecology has included a catchall statement which basically forces the potentially liable person to comply with Ecology's food web model if the agency doesn't like the substitute values or species proposed.

Less expensive. Ecology has stated in the Small Business Impact Statement that there will be an increase in costs for certain small businesses of $20 \%$. This clearly indicates that the proposed rule is not less expensive. Furthermore, from this analysis, it can be concluded that there will undoubtedly be a proportionate increase for large businesses as well.

It is clear from the above that Ecology has not followed through on the standard they set for this rulemaking which was to make it fairer, easier to understand, flexible, less ambiguous, and less expensive. It is also clear that Ecology has not followed the directive in Governor Locke's Executive Order 97-02, which states that "rules be written and organized so they may be easily understood and used by people who are affected by them." Due to the lack of clarity, much of the regulation will be left to individual Ecology personnel to interpret and implement, resulting in inconsistent application throughout the state and a strong likelihood that cleanup decisions will be based on the preference of individual regulators rather than defensible remedies resulting from balanced and objective evaluations.

Ecology has also still not addressed a number of issues that are of concern to facilities. These issues were raised in a series of meetings with Ecology's facilitator and mid level management in the Toxic Cleanup Program as well as Ecology senior level management. While certain stakeholders present at these meeting felt they had reached agreement, Ecology did not follow through on its commitments and hence, these issues have never been resolved. We continue to have major concerns about the proposed rule and recommend that Ecology put the rulemaking on hold pending resolution of these concerns.

3. Land-use planning authority: Land-use is an important factor in implementing MTCA cleanup actions, particularly with regards to establishing cleanup levels for industrialzoned properties. The current and proposed regulation acknowledges the authority of cities and counties in land-use planning. To clarify for the regulated community, does Ecology assert any independent land-use planning authority in making MTCA cleanup decisions, or will Ecology always accept local land-use planning efforts? E.g., if a city planning pursuant to the Growth Management Act (GMA) zones a property as industrial, does Ecology nevertheless reserve the right to require cleanup to a residential standard? If so, what criteria would Ecology use to reject the city's GMA authority? Please clarify the Ecology position on this matter in the Responsiveness Summary for this rulemaking effort.

4. Relationship to Federal Cleanup Program: The MTCA revisions should be modified to state that a cleanup action selected under the Comprehensive Environmental Response, Compensation, and Liability Act (CERCLA) will be deemed to satisfy the requirements of MTCA provided that the cleanup action incorporates and complies with the substantive provisions of MTCA, as acknowledged by Ecology signature on the decision document for the CERCLA cleanup action. This would eliminate the jeopardy faced by potentially responsible parties of completing an approved cleanup action under the federal cleanup law only to face the possibility of a subsequent cleanup action imposed pursuant to MTCA. This concept could be included in the MTCA regulations by making changes to the language proposed in WAC 173-340-380(4). 
5. Intended Impact on Cleanup Actions; As with the draft rule, the proposed rule is unclear regarding the intended impact that Ecology foresees based on the new requirements. To address this matter, please provide answers to the following questions in the Responsiveness Summary for this rulemaking effort:

- From an historical perspective, approximately what percentage of MTCA cleanups have attained the fully "unrestricted land use" cleanup levels rather than using containment, institutional controls, or relying upon a different exposure/use scenario?

- Is it Ecology's belief that the proposed regulation would result in a higher, lower, or about the same percentage of cleanups to fully unrestricted land use levels?

6. Use of individuals rather than populations in ecological risk: In the pre-proposal draft of WAC 173-340-7490 through 7494, Ecology built their premise of significant adverse affects from contaminants on impacts to populations, except in the case of threatened and endangered species. This was the correct ecological approach and was consistent with environmental law and guidance established by EPA under 43 CFR 11. It appears that the proposed rule has changed the level of significant effect to the point where non-threatened and non-endangered species are treated the same as threatened and endangered species so that impact to an individual would be considered unacceptable. The pre-proposal stated that "the significance of an adverse effect is evaluated relative to an impacted local population of species of concern." It also went on to consider significant impacts as those that would alter "important structural or functional characteristics or components of the affected ecosystem." It appears that Ecology has removed the reference to population effects in order to justify more stringent soil cleanup standards. This is inappropriate. The rule should be revised to focus on protection of populations.

\section{Specific Issues}

1. WAC 173-340-120(2)(a): The proposed revisions would delete the sentence indicating that reporting of most current releases (as opposed to past releases) is required under the state's hazardous waste, underground storage tank, or water quality laws. What is the intent of this deletion? Is Ecology implying that additional reporting requirements have been added as part of this rulemaking effort, such that the previous reliance on other laws for reporting of current releases is no longer correct? It would appear that additional reporting may be intended based upon proposed provisions pertaining to independent remedial actions, but the rule is not clear on this matter. The existing proposal is inadequate if such additional release reporting is expected. If additional reporting of releases is required, specific regulatory language should be developed and presented to the public for comment.

2. WAC 173-340-120(3)(a): The language in this section states that Ecology will notify the public "if the department decides that no further action is required." From the Responsiveness Summary for the February 1991 amendments to WAC 173-340 it is clear that Ecology does not require site listing or cleanup in all situations, even if a cleanup level is exceeded. Please identify, in the regulation, the criteria that Ecology will use to decide that no further action is necessary at a site. 
3. WAC 173-340-120(8)(b): This section allows for independent remedial actions. The proposed changes to the rule require that such actions be reported to Ecology, with no threshold below which such reporting would not be necessary. This is a significant change from the existing rule, which requires reporting in accordance with WAC 173-340-300. The current regulation at WAC $173-340-300$ requires reporting only of those releases that the facility owner/operator determines to present a threat to human health or the environment. Under the proposed language of WAC 173-340-120(8)(h) and WAC 173-340-515, arguably every release and independent cleanup action would require reporting. Is it really Ecology's intent that, for example, a cleanup of a small leak of antifreeze from a fleet motor vehicle be reported as an independent cleanup action? If so, the proposed standard represents an entirely unrealistic and non-implementable requirement. If this is not the intent, the regulatory language needs to be revised to establish the threshold above which reporting would be required. It is suggested that Ecology maintain the approach taken in the current regulation; i.e., reporting is required pertaining to the discovery and cleanup of releases that the facility owner/operator determines to pose a threat to human health and the environment.

4. WAC 173-340-200, "natural attenuation" definition: In order to properly reflect the viability of natural attenuation in certain circumstances, the following sentence should be added to the end of the proposed definition: "However, natural attenuation could represent an appropriate remediation method provided it is protective of human health and the environment and it is capable of achieving cleanup objectives within a timeframe that is reasonable compared to more active remedial measures."

5. WAC 173-340-300(2)(b): The proposed language provides "examples" of situations where a release "generally" would require reporting as a potential threat to human health or the environment, subject to the facility owner/operators best professional judgement. Although providing examples is helpful, care must be taken to ensure that the list is not misconstrued by individual Ecology regulators as enforceable regulatory requirements that automatically trigger reporting in every instance. Please confirm, in the Responsiveness Summary for this rulemaking effort, that the rule does not necessarily require reporting in every instance where one of the "examples" is encountered. Additionally, item (viii) in the list of examples ("sites where chemicals have leaked or been dumped on the ground") should either be deleted or clarified and re-proposed. What exactly is a "chemical" within the scope of this item? Is table salt (sodium chloride) a chemical? How about antifreeze? Gasoline? Oil? What quantity of chemical must be present before reporting under this item would be expected? A grain of salt? A drip of oil or antifreeze? Or only a quantity that the facility owner/operator determines poses a threat? If the latter, the item should be deleted: reporting of such releases are already required under this section, and this unqualified and unquantified example merely adds confusion.

6. WAC 173-340-310(5): New language in this section would give Ecology the authority to determine, on a case-by-case basis, "the method and nature of the notification" to be given to people in the potentially affected vicinity. This appears to give Ecology unconstrained authority on this matter, leaving implementation to the whim of individual Ecology personnel. This is inappropriate. Instead, the regulation should propose fairly specific criteria and requirements for the sort of notifications Ecology may typically impose, with a case-by-case allowance for a more extensive notification effort if approved by the Manager of Ecology's Toxic Cleanup Program.

7. WAC 173-340-350(8)(c)(ii)(A): In order to create internal consistency, this provision should be revised to read: "Except as provided in (B) (below), the feasibility study shall include ..." 
8. WAC 173-340-350(8)(c)(ii)(B): What are the criteria for determining that the cost of a permanent alternative "is so clearly disproportionate that a more detailed analysis is not necessary?" Clear to whom? Is this a subjective "we'll know it when we see it" judgement? The regulation should be revised to identify, at a minimum, some "rules of thumb" criteria for determining "clearly disproportionate" cost. Additionally, Ecology should consider establishing a statewide remedy review board (similar to EPA's National Remedy Review Board) in an effort to ensure statewide consistency in remedy selection.

9. WAC 173-340-350(9)(a)(ii): This provision establishes a threshold requirement that cleanup actions comply with cleanup standards. The definition in WAC 173-340-700(3) states that the term "cleanup standards" consists of, among other things, cleanup levels. Does the threshold requirement in $-350(9)(a)(i i)$ therefore require that cleanup actions comply with cleanup levels? How can this be, when elsewhere the MTCA regulations clearly allow for use of remediation levels? The confusing regulatory provisions pertaining to cleanup actions, cleanup levels, and remediation levels - so evident in the pre-proposal draft revisions continue throughout this proposed rule. The regulation should be revised in several places to indicate, in understandable terms, that cleanup to "cleanup levels" is not always required (although such cleanup is one option) and that cleanup to remediation levels (which should be re-defined as a numerical standard) is allowed. The regulation should be revised to clearly reflect the concept of a "cleanup action" as opposed to a "remediation level." The latter implies a concentration-based standard as opposed to an action (consistent with the proposed definition), however; the regulation appears to use the term in instances where "cleanup action" or "cleanup action alternative" would be more appropriate.

10. WAC 173-340-350(9)(e)(ii): This section specifies that cleanup actions shall not rely primarily on institutional controls and monitoring if it is technically practicable to use a more permanent action. The "shall" should be change to "should" or indicate that this is a "strong preference." There may be instances where it would be most beneficial to simply implement institutional controls. For example, if an area is a designated wildlife habitat and the only unacceptable risk would be to a year-around residential user (i.e., contaminant levels do not present a risk to wildlife), it might be better in terms of avoiding disruption to the wildlife to implement institutional controls and monitoring.

11. WAC 173-340-350(9)(e)(ii): This section should state that cleanup actions should not rely primarily on institutional controls and monitoring where it is technically practical to implement a permanent solution, rather than where it is technically possible.

12. WAC 173-340-350(13)(d)(iv): Under CERCLA, a waiver is allowed if it can be demonstrated that cleanup to a certain level is technically impracticable. The proposed MTCA regulation states that the action cannot be finalized and must be considered interim in situations where attainment of the cleanup level is technically impracticable. However, a technical solution may never exist in a "reasonable time frame." A provision should be added to this section allowing an action to be "final" if it is demonstrated that is technically impracticable to meet a cleanup level. It is also unclear why the exception for cleanup levels that are below technically possible concentrations would be allowed only for Method $\mathbf{C}$. Please clarify.

13. WAC 173-340-390(2): What is the process Ecology intends to use for establishing a model remedy? Will an opportunity for public comment be afforded? Or will Ecology unilaterally establish model remedies with no formal public input? It is recommended that the rule be 
revised to identify the process Ecology will use for establishing model remedies. Public comment should be an integral part of the model remedy process.

14. WAC 173-340-515: This new section establishes various standards for conducting independent remedial actions, including requirements for submitting written reports to Ecology. There is no threshold established for when reporting would be unnecessary. Does Ecology really intend that the facility owner/operator prepare and submit a written report to document cleanup of a few drops of hazardous substance (e.g., a leak of antifreeze from a fleet automobile)? Or is the intent that reporting is required only when the owner operator concludes that the release presented a threat to human health or the environment (presumably considering, among other things, the "examples" shown in WAC 173-340-300(2)(b))? As currently written, there is no lower threshold for reporting independent cleanup actions, placing an unreasonable burden on the regulated community. The rule should be revised to indicate that reporting is required only is situations where the release presents a threat to human health or the environment.

15. WAC 173-340-700(5)(b); WAC 173-340-700(5)(c); WAC 173-340-706(1)(b): Based on the language in Section 706(1)(b), it appears that Ecology has now restricted use of Method C for soils to industrial soils only. Method $C$ could not be used for recreational/agricultural land uses; instead, the "modified Method B" would be used to develop cleanup levels under these alternative land use scenarios. Is this understanding correct? There may be clear instances (e.g., golf courses, parks, etc.) where residential use is as unlikely as at industrial sites and greater flexibility than allowed under standard Method B is appropriate. Perhaps this could be accommodated by use of modified Method B. Is this Ecology's intent? If not, what is the regulatory mechanism for establishing cleanup standards for non-residential, nonindustrial land use scenarios?

Additionally, in order to remain consistent with current MTCA provisions, Section 700(5)(b) should be revised to state that under modified (but not standard) Method B the cleanup level for individual carcinogens is based upon a lifetime cancer risk of one in one hundred thousand $\left(1 \times 10^{-5}\right)$ rather than a one in one million risk. This language also needs to be included in the sections addressing cleanup standards for the specific media.

16. WAC 173-340-702(10): This section should be revised to state that cleanup actions selected under the federal cleanup law which (1) incorporate substantive provisions of MTCA, and, (2) are approved (or co-approved in conjunction with EPA) by Ecology shall be deemed to satisfy the requirements of MTCA. This would eliminate the jeopardy of completing an approved cleanup action under the federal cleanup law only to face the possibility of a subsequent cleanup action imposed under MTCA.

17. WAC 173-340-705(2)(c), various other locations: In order to be consistent with current Ecology policy as well as the language in the draft rule at Section 705(5), add a statement to this section indicating that cleanup levels under applicable state and federal law shall be considered sufficiently protective provided the associated cancer risk does not exceed one in one hundred thousand or a hazard index of one. Similar statements need to be included at various other locations in the regulation. Without such language, the regulation could be interpreted to require Method B cleanup to a one in one million cancer risk (being the most stringent limit) in situations where a state or federal cleanup limit represents a cancer risk in excess of one in one million, but less than one in one hundred thousand. (Note that the regulatory language requires that Method B cleanup levels be at least as stringent as all the 
listed criteria, implying that calculated cleanup levels would take precedence over levels based on applicable law when the former are more stringent.)

18. WAC 173-340-706(1)(a)(i): Language retained in this section states that "[w]here Method A or Method B cleanup levels are below area background concentrations, Method C cleanup levels may be established at concentrations that are equal to area background concentrations, but in no case greater than concentrations specified in subsection (2) of this section." Subsection (2), however, specifies a hazard quotient no greater than 1 and carcinogenic risk no greater than one in one hundred thousand. This requirement could require a cleanup standard that, in certain situations, is below background levels. In contrast to the Section 706(1)(a)(i) provisions, Sections 700(6)(e) and 706(6) merely (and reasonably) provide that Method B and Method $C$ cleanup levels do not need to be set below background levels. It is recommended that Section 706(1)(a)(i) be deleted.

19. WAC 173-340-708(5)(f): The proposed language in this section is confusing. Consider revising along the following lines: "When making adjustments to cleanup levels and remediation levels for multiple hazardous substances, the concentration levels for individual hazardous substances shall not be established lower than the practical quantitation limit or natural background levels."

20. WAC 173-340-709(3): The title to this subsection is inappropriate. It should be changed to something like "Statistical Analysis."

21. WAC 173-340-720; WAC 173-340-747: These sections should state which groundwater cleanup level should be used when values of both the Reference Dose and Cancer Potency Factor are available to calculate two groundwater cleanup levels (e.g., using Equation 720-1 and Equation 720-2).

22. WAC 173-340-720(4)(b)(ii)(A), Equation 720-1: In order to use this equation it must be determined if the parameter "INH" is 2 for volatile hazardous substances or 1 for all other substances. How is it determined if a hazardous substance is regarded as "volatile"? No citations for this determination have been provided.

23. WAC 173-340-720(4)(b)(ii)(A) and (B), Equations 720-1 and Equation 720-2: These equations are used to calculate Method B or C groundwater cleanup levels in units of micrograms per liter. However, Equation 747-1 in WAC 173-340-747 calls for use of the groundwater cleanup level calculated from WAC 173-340-720 in units of milligrams per liter. This discrepancy invites serious calculation errors that could cause those who are regulated by MTCA to make one thousand-fold errors in calculation of soil concentrations protective of groundwater. Equation 747-1 should be rewritten to include groundwater cleanup level calculated from WAC 173-340-720 in units of micrograms per liter with a conversion factor to convert from micrograms to milligrams.

24. WAC 173-340-720(8)(b): The proposed language appears to require a downward adjustment of cleanup levels based on applicable state or federal law in situations where such levels exceed a cancer risk of one in one hundred thousand or a hazard index of one. This allowance presupposes that the applicable state/federal law standards may be used in lieu of the calculated MTCA carcinogen and noncarcinogen cleanup levels, even when the latter are more stringent. Yet the regulatory provisions (e.g., at WAC 173-340-720(3)(b)) require that cleanup levels be "at least as stringent as all" of the applicable or calculated values, indicating that the more stringent standard would always establish the cleanup level. I.e., a 
cleanup level based on applicable state or federal law could not be used if the calculated MTCA cleanup level was lower. In order to accommodate use of applicable standards in lieu of more stringent calculated levels (presuming the former do not exceed the one in one hundred thousand/hazard index of one criteria), the requirements in sections (3), (4), (5), (6), and (7) need to be revised accordingly.

25. WAC 173-340-720 (10)(d)(iii). We are concerned that the standards given in the revised MTCA tables are derived using a flawed method. We are also concerned about the presumption that groundwater levels exceed cleanup levels (definition of "null hypothesis" in 173-340-200). While this is appropriate when the cleanup levels are concentration-based, the MTCA amendments shift the cleanup levels to background levels in some cases. It is inappropriate to assume that the groundwater contains more than background levels as a starting hypothesis.

Cleanup levels are based on risks, ARARs, ecologically protective levels, etc. The statistical test is one-sample test (i.e. evaluating the site data versus a constant or fixed value). However, when the cleanup levels are based on background, the statistical test is two-sample case (i.e. evaluating the site data versus background data). Currently, the default method [as specified the compliance monitoring (WAC 173-340-720(10)] uses a single numerical value as the cleanup standard, to which site data is compared. To treat background-based cleanup levels as constants (known without error) will make it more difficult to simultaneously achieve a desirable (low) false positive error rate and a high statistical power to detect residual contamination if background data sets are highly variable (i.e. highly skewed distributions). Alternative distribution testing methods (e.g. the Wilcoxon Rank Sum test and Quantile test) should be specified in WAC 173-340-720(10)(d)(iii).

26. WAC 173-340-740(1)(a): The requirements in this section appear to allow only two types of exposure scenarios: unrestricted residential use or industrial use. What about use of modified Method B for land uses such as commercial or recreational? These scenarios may include engineered/institutional controls on the land. Therefore, either this section should state that soil cleanup standards under modified Method B can allow contamination to be left above unrestricted land use levels in alternative land use scenarios or (preferably) another section should be added after this section acknowledging that restrictions on land use are acceptable under certain circumstances.

27. WAC 173-340-740(7)(d)(i)(B), Last sentence: Editorial comment: sentence should read ". . whether the data are log-normally or normally distributed."

28. WAC 173-340-745(5)(b)(ii): This section requires that contaminants left in industrial soil not cause groundwater to exceed cleanup levels established under WAC 173-340-720. Which -720 groundwater cleanup levels are being referred to, Method $C$ levels (corresponding to use of Method $\mathbf{C}$ for establishing industrial soil standards) or Method B levels (unless, under the -720 criteria, Method $C$ levels can be justified)? The language in WAC 173-340-745(b)(iv) appears to imply that the latter situation may apply, but it seems natural to associate Method C industrial soil cleanup levels with the Method C groundwater cleanup levels. Please clarify.

29. WAC 173-340-747: This section establishes a variety of methods for establishing soil cleanup concentrations for groundwater protection: two "standard Method B" methods and four "modified Method B" methods. Although there are certain identified limitations regarding use of some of the methods, it is generally unclear which methods are to be used, 
and who makes the decision. For example, under standard Method B, is the most stringent soil cleanup concentration derived from the two allowable methods used? Or can either method be used? In the latter case, who decides which method to apply? Ecology or the regulated entity? In a similar manner, if methods under both the standard or modified approach could be utilized for a constituent, what are the criteria for selecting which method to use, and who makes the decision? The regulation should be revised to address these issues and re-proposed for public comment before finalization.

30. WAC 173-340-747(3)(a), Equation 747-1: The information provided to implement Equation 747-1 has serious deficiencies. Table 747-1 provides Distribution Coefficients (Kd) for 10 metals. What Distribution Coefficients should be used for other metals? Antimony, barium, manganese, and silver are examples of metals that are important in the environment for which no Distribution Coefficients are defined.

The Henry's Law Constant used in Equation 747-1 should be defined in WAC 173-340-200 and discussed with other parameters in WAC 173-340-700. As it stands it is a "mystery number" to those who are regulated by MTCA.

The value to be used for Henry's Law Constant for metals in Equation 747-1 is not defined. Presumably the value would be zero, but it should be defined.

What groundwater cleanup levels should be used for lead $(\mathrm{Pb})$ and mercury $(\mathrm{Hg})$ to implement WAC 173-340-747 using Equation 747-1? Lead and mercury do not have values of Reference Dose or Cancer Potency Factor needed to implement Equation 720-1 or Equation 720-2 in WAC 173-340-720.

31. WAC 173-340-747(3)(a)(i), Equation 747-2: Several important organic chemicals have no value of Koc to use to calculate the Distribution Coefficient $(\mathrm{Kd})$ using this equation. For example, what value of Koc should be used to calculate $\mathrm{Kd}$ for ethylene glycol, methanol, or methyl isobutyl ketone?

32. WAC 173-340-747(3)(b): Guidance should be included on the types and number of samples to be used when employing the leach test procedure.

33. WAC 173-340-747(3)(b)(ii)(A and B): Most of the metals listed in these sections have TCLP detection limits far above the MTCA B groundwater standards. For example, a typical TCLP detection limit for cadmium is $1 \mathrm{mg} /$; the Method B groundwater limit $0.008 \mathrm{mg} / \mathrm{L}$. The situation for arsenic is much more disparate. Either these criteria should be revised or these metals should be excluded from the leach tests.

34. WAC 173-340-747(4)(b): Although the increased flexibility allowed by the proposed rule is a welcome alternative to the " $100 \mathrm{X}$ " rule, there is little guidance on sample requirements for determining site-specific parameters. Areas with complex hydrology would require many more samples than areas with relatively homogeneous stratigraphy. Once the data are collected, what statistic will be used (average, upper or upper bound?) to represent the area?

35. WAC 173-340-7490(3) Goal: This paragraph is vague in its definition of significant adverse effects to species other than the threatened and endangered species. It appears that some undefined, sub-lethal effect to an individual could be construed as a significant effect that could drive a cleanup standard. Please define what is meant and which laws are being 
referred to in the statement "other applicable laws that extend protection to individuals of a species."

36. WAC 173-340-7491(1)(c)(iii): Reference is made to Table 6 . There is no Table 6 supporting these sections. Is table 749-1 the intended table?

37. WAC 173-340-7492 (2)(c)(i): Reference is made to Table 7. Should this say "Table 749-2?"

38. WAC 173-340-7493(2)(a)(i): At the end of this paragraph is a caution statement that says the ecological indicator concentrations found in Table 749-3 are "not cleanup levels." Later in this subsection under 7493 (3), it says that the concentrations given in Table 749-3 "may be used as the cleanup levels" at the discretion of the person conducting the evaluation. Explain the inconsistency.

39. WAC 173-340-7493(3): An additional subsection is appropriate to help guide the evaluation and use of the results obtained. For instance, the ecological relevance of the concentrations of contaminants to the local ecosystem and the potential ecological effects of the cleanup should be weighed. A cleanup action may cause more damage than it resolves and alternate mechanisms for dealing with the site may be preferable. Performing mitigation at another site, rather than remediating relatively low levels at the subject site, could be more useful to the habitat and wildlife. Innovative ways to approach each problem should be encouraged.

40. WAC 173-340-7493(3)(b)(i): Revise the last sentence to read as follows: "Other bioassay tests approved by the department may also be used and may be preferable for ecological reasons (e.g., soil types at the site are unsuitable for the earthworms)."

41. WAC 173-340-7493(7): Table 9 is referred to twice in this subsection when it should be Table 749-4.

42. WAC 173-340-7493(7)(f): This paragraph says that to account for uncertainties associated with substitute receptor species, Ecology may require use of toxicity reference values based on no observed adverse effects levels (NOAELs), use of uncertainty factors to account for extrapolations of toxicity or exposure parameter values between species, or use of a hazard index approach to account for additive toxic effects. This appears to be the catchall statement that says if Ecology doesn't like the substitute values or species proposed, (even though they are just as valid and substantiated as the ones they selected in their model) they will force the potentially liable person to comply with the food-web model provided. If any of these measures (NOAELs, uncertainty factors, or hazard index) are applied, the resultant cleanup level will be lowered by at least a factor of 10; making the whole exercise of proposing surrogate species and input parameters futile. This represents a double standard because Ecology didn't apply these extra-conservative measures (which are not scientifically based) in the development of their standard food-web model and shouldn't be allowed to impose them just because they don't like the results of a proposed modified model. Item " $f$ " should be deleted from this subsection.

43. WAC 173-340-7494(2): This paragraph is unclear. It is not clear what is meant by "protection of wildlife for industrial and commercial land uses, and upon protection of plants and animals for other land uses." Is there a difference between the reference to wildlife and the reference to plants and animals? It would be more clear to say "Table 749-2 shall be 
based on protection of wildlife and terrestrial receptors for commercial land uses and other land uses."

44. WAC 173-340-990: The tables in this section must be presented in numerical sequence with correct numbers. However, it would be more user-friendly to present the tables in the sections where they are actually used. This would also eliminate the current confusion of having the small tables in the text of the sections and the large tables located elsewhere. This has caused Tables 747-3 and 747-4 to be incorrectly numbered as 747-1 and 747-2 in WAC 173-340-990.

45. WAC 173-340-990, Table 720-1, "Method A Cleanup Levels for Ground Water," lead entry: The lead entry in this table ( 5 micrograms/liter) is, according to the footnote, based on federal law at 40 CFR 141.51. The MCLG for lead in 40 CFR 141.51 is zero based on carcinogenic properties. According to WAC 173-340-720(3)(b)(ii)(B), only noncarcinogenic MCLG values are to be used in establishing Method A limits. There is no MCL for lead. There is, however, an action level of 15 micrograms/liter established in 40 CFR 141 Subpart I. State Department of Health regulations at WAC 246-290 reflect the 40 CFR 141 Subpart I standards. To be consistent with the stated criteria for establishing Method A values, Ecology should not use the 0 micrograms/liter MCLG based on carcinogenic properties, but instead should use the 15 micrograms/liter action level.

46. WAC 173-340-990, Table 740-1, "Method A Soil Cleanup Levels for Unrestricted Land Uses," lead entry: The $250 \mathrm{mg} / \mathrm{kg}$ cleanup level for lead is purportedly based on "preventing unacceptable blood lead levels." This appears to be an outdated value. Ecology has used EPA's Integrated Exposure Uptake Biokinetic (IEKBK) Model to establish lead cleanup levels for MTCA cleanups. (E.g., see memo, Mr. Mike Blum (Ecology) to Messrs. Vern Moore (Weyerhaeuser Company) and Jack Frazier (DuPont Company), Re: Residential SoilLead Cleanup Standards for Former DuPont Works Site, dated October 1, 1997.) This model was specifically designed to identify levels of lead in the environment that could result in unacceptable blood lead levels in children (the most susceptible population). Using the conservative default values in the IEUBK model, a soil cleanup level of $353 \mathrm{mg} / \mathbf{k g}$ is derived for residential soil. This value should be reflected in Table $A$ in lieu of the archaic 250 $\mathrm{mg} / \mathrm{kg}$ cleanup level.

47. WAC 173-340-990, Table 749-3: The intended use of the plant and soil biota concentrations in Table 749-3 is unclear. Will Ecology choose to use the lowest concentration for a chemical in the table similar to the selection process for the reported concentration from the wildlife exposure model? If so, there needs to be an explanation of how the plant and soil biota concentrations were selected from the Oak Ridge documents, so the regulated community can assess the applicability of those values to their waste sites. 